\title{
Mandenkan
}

MANDENIKAN Bulletin semestriel d'études linguistiques mandé

$56 \mid 2016$

Numéro 56

\section{A prosodic perspective on the assignment of tonal melodies to Arabic loanwords in Bambara}

La perspective prosodique de l'attribution des mélodies tonales aux emprunts arabes en bambara

ПРОСОДИЧЕСКАЯ ПЕРСПЕКТИВА ПРИПИСЫВАНИЯ ТОНАЛЬНЫХ КОНТУРОВ

АРАБСКИМ ЗАИМСТВОВАНИЯМ В БАМАНА

Christopher R. Green and Jennifer Hill Boutz

\section{(2) OpenEdition}

1 Journals

Electronic version

URL: https://journals.openedition.org/mandenkan/999

DOI: 10.4000/mandenkan.999

ISSN: 2104-371X

Publisher

Llacan UMR 8135 CNRS/Inalco

\section{Printed version}

Date of publication: 1 December 2016

Number of pages: 29-76

ISSN: 0752-5443

\section{Electronic reference}

Christopher R. Green and Jennifer Hill Boutz, "A prosodic perspective on the assignment of tonal melodies to Arabic loanwords in Bambara", Mandenkan [Online], 56 | 2016, Online since 17 February 2017, connection on 08 July 2021. URL: http://journals.openedition.org/mandenkan/999 ; DOI: https:// doi.org/10.4000/mandenkan.999

This text was automatically generated on 8 July 2021.

\section{c) (i) (2)}

Les contenus de Mandenkan sont mis à disposition selon les termes de la Licence Creative Commons Attribution - Pas d'Utilisation Commerciale - Partage dans les Mêmes Conditions 4.0 International. 


\title{
A prosodic perspective on the assignment of tonal melodies to Arabic loanwords in Bambara
}

\author{
La perspective prosodique de l'attribution des mélodies tonales aux emprunts \\ arabes en bambara \\ ПРОСОДИЧЕСКАЯ ПЕРСПЕКТИВА ПРИПИСЫВАНИЯ ТОНАЛЬНЫХ КОНТУРОВ \\ АРАБСКИМ ЗАИМСТВОВАНИЯМ В БАМАНА
}

Christopher R. Green and Jennifer Hill Boutz

\section{AUTHOR'S NOTE}

We would like to thank Stuart Davis, Valentin Vydrine, and audience members at the CUNY Conference on Weight in Phonology and Phonetics for comments on portions of this work. We also thank two anonymous reviewers whose comments have helped us to significantly improve the quality of this paper. Of course, any remaining shortcomings are our own responsibility.

\section{Introduction}

1 Islam has a long history in Mali, and thereby, it has had a lasting influence on Bambara (Bamana, Bamanankan; iso:bam). According to a 2005 United States Library of Congress report, upwards of ninety percent of Malians are Muslim, and similarly, nearly eighty percent of Malians speak some variety of Bambara as a first or second language (Lewis et al. 2014). Many Arabic words have been borrowed into Bambara as a result of this longstanding influence of Islam in Mali, with some earlier sources estimating that at least twenty percent of the Bambara lexicon may be borrowed from Arabic (e.g., Delafosse 1929/1955). Some sources appear to indicate a lower percentage (e.g., 
Bailleul 2007; Dumestre 2011), while analyses by Tamari (2006, and references therein) imply that twenty percent may be an underestimate.

2 Regardless of the exact percentage of Arabic borrowings in Bambara, it is clear that they have become "very well integrated" (Dumestre 1983) into the language's lexicon. The contact situation between the two languages is such that Arabic entered the Bambara lexicon primarily via "learned orality" through marabouts (West African Islamic religious leaders) and Qur'anic instruction and secondarily via written transmission (Zappa 2009, 2011). Zappa's works details the ways in which Arabic borrowings have been adapted and oftentimes nativized into the Bambara lexicon from the standpoint of morphology, syntax, and semantics; however, he correctly points out that the phonological influences (and particularly the tonal influences) on the borrowing situation have not yet been discussed in detail. We address this gap in the current paper. We will follow the assumption laid out in Zappa (2011) that because the source of the majority of Arabic loanwords lies undeniably in Islam, Classical Arabic (henceforth Arabic, unless otherwise stated) is an appropriate baseline upon which to base our analysis of the loanword adaptation process. This is particularly relevant for the relatively large class of lexical items that are either directly or indirectly related to religion that have been borrowed into Bambara from Arabic. Of course, we cannot rule out the possibility that other Maghrebi Arabic dialects such as Hassaniya, Algerian, Libyan, and Moroccan may have exerted some influence.

3 In addition to this religious vocabulary, there is also a sizable class of Arabic borrowings in Bambara related to trade and commerce. Dumestre (1983) proposes that it is likely that these words have been borrowed through an intermediary language (in particular, via Soninke) and therefore may be more phonologically divergent than direct borrowings within the field of religion. While there has yet to be any systematic comparison of these divergences, we have explored some potential influences that Soninke may have had in the loanword incorporation process. As we illustrate later in this paper, Soninke appears not have exerted any substantive influence on the process.

of primary concern to us are mismatches between the phonologies of Arabic and Bambara, both segmental and suprasegmental, which must be accommodated for in the process of loanword incorporation. In this paper, we explore prosodic (i.e., tonal and metrical) incompatibilities between the phonologies of the two languages and their consequences for the process of loanword incorporation. On the borrowing end, Bambara makes use of contrastive lexical and grammatical tone, has no consistent phonetic correlates of stress, and has a fairly conservative inventory of permissible syllable types. ${ }^{1}$ Arabic, however, is non-tonal, has predictable syllabic and morphologically-conditioned rules of stress placement, and permits a variety of complex syllable types in different word positions. By complex syllables, we mean syllables other than those that match Bambara's canonical maximal CV syllable template (e.g., $\mathrm{CCV}$ and $\mathrm{CVC}$ ).

5 Certain foundational components of our analysis follow from the assertions of many before us (e.g., Bambara 1991; Green 2010; Leben 2002, 2003; Rialland \& Badjimé 1989; Weidman \& Rose 2006; Vydrine 2002, 2010). Each of these works has illustrated that foot structure plays a key role in Bambara phonology. The data that we present below also lend support to the assertion in Green $(2010,2015)$ that Bambara's prosodic structure is built upon trochaic (left-headed) feet, a perspective that we further explicate below. Importantly, Green has argued that structural constraints on 
Bambara's foot structure actively militate against the application of certain segmental deletion processes that would result in the creation of iambic (right-headed) feet, at least in some varieties of the language. Arabic, on the other hand, has a largely weight-sensitive iambic foot structure (McCarthy \& Prince 1990). We aim to show that the prosodic mismatches between these two languages contribute to the outcomes of tonal melody assignment in Arabic borrowings, rendering them different in some ways from that found in Bambara words of non-Arabic origin.

6 We approach the remainder of this paper as follows. First, we outline and explain our analytical assumptions concerning the underlying characteristics of Bambara tonology, the state of the science concerning the assignment of tonal melodies in the language, and the importance of prosodic structure in Bambara phonology. We then discuss segmental and suprasegmental mismatches between Bambara and Arabic before presenting data detailing the distribution of tonal melodies in Bambara words of both Arabic and non-Arabic origin, as indicated in the sources that we have consulted. Our analysis probes characteristics of tonal melody distribution related to prosodic structure in Arabic borrowings that are not treated fully in earlier analyses. We then close with points for discussion and concluding thoughts.

\section{Preliminaries on Bambara tonology}

7 There are at least three points of view concerning the underlying mechanics of Bambara tonology. The assimilationist approach (e.g., Courtenay 1974; Leben 2002, 2003; Green 2010, 2015) argues that the vast majority of Bambara words are lexically assigned either a High (H) or Low-High ( $\mathrm{LH})$ tonal melody. At the word level, a LH melody will alternate to all-L under certain conditions via a process known as affaissement or settling (Dumestre 2003:25). The dissimilationist approach (e.g., Bird 1966; Creissels 1978; Diarra 1976; Dumestre 1987) instead argues that the underlying melodies are $\mathrm{H}$ and $\mathrm{L}$ and that a L melody will dissimilate to $\mathrm{LH}$ under analogous conditions, although for different reasons. A third approach proposed in Creissels \& Grégoire (1993) and later revised and refined in Creissels (2009) assumes that only L tones are lexically-specified in the language, with $\mathrm{H}$ tones being later inserted by default.

8 In this paper, we adopt an assimilationist perspective in our analysis of the distribution of Bambara tone melodies. We do this for a number of reasons that are grounded in cross-linguistically well-attested principles of tonology such as those raised in works like Hyman \& Schuh (1974) and Hyman (2007). Important among these principles is the naturalness of assimilatory tonal processes. That is, it is cross-linguistically observed that tonal assimilation within a defined span is a phonetically natural process of sound change. Such processes contribute to a minimization of so-called tonal 'ups and downs' in a given sequence. Tonal dissimilation, on the other hand, is in most instances a phonetically unnatural process in that it increases, rather than decreases, the number of tonal rises and falls that occur in a sequence. The aforementioned authors discuss that although instances of tonal dissimilation have sometimes been successfully argued for in the literature, they tend to be morphologically-triggered. While in some instances in Bambara (e.g., in mono- and disyllabic words), one could perhaps argue that a change of /L/ $\rightarrow[\mathrm{LH}]$ is morphologically-triggered (e.g., preceding the language's floating $\mathrm{L}$ tone definite marker), such a morphology-based explanation would not be 
extensible to situations in which the purported /LLH/ melody of some trisyllabic words dissimilates to [LHH] within a single word. It is for these reasons and due to other correlations between assimilatory tonal spreading, segmental constituency, and prosodic structure discussed further below that we adopt an assimilationist analysis of Bambara tone. We do so in full acknowledgement that this standpoint is not shared by all others who have worked or currently work on Bambara.

With our motivations concerning our assimilationist perspective in place, we can illustrate a foundational fact of Bambara tonology that there is a contrast between $\mathrm{H}$ and LH tonal melodies, as in . In these examples and throughout this paper, we indicate a High $(\mathrm{H})$ tone with an acute accent and a Low (L) tone with a grave accent. A LH sequence on a single vowel is indicated by a rising tone.

(1) Contrastive $\mathrm{H}$ vs. LH tone melodies

\begin{tabular}{|l|l|l|l|l|l|}
\hline & Bambara & Gloss & & Bambara & Gloss \\
\hline a. & bá & 'river' & g. & bílén & 'fly (insect)' \\
\hline b. & bǎ & 'goat' & h. & bilén & 'red' \\
\hline c. & fá & 'to fill' & i. & fúrá & 'leaf' \\
\hline d. & fã & 'father' & j. & fùrá & 'distance' \\
\hline e. & sán & 'sky' & k. & kóró & 'underside' \\
\hline f. & săn & 'year' & l. & kòró & 'old' \\
\hline
\end{tabular}

10 The distribution of these tonal melodies becomes more complicated in longer monomorphemic words and particularly in odd-parity trisyllabic words that are lexically assigned the /LH/ melody. This complication arises because, in these words, the two tones of the /LH/ melody must be distributed across three syllables. This distribution follows an autosegmental distribution of tones across tone bearing units (TBUs), and we follow Green (2015) in assuming that the Bambara TBU is the mora.

11 The vast majority of trisyllabic Bambara words have surface [HHH], [LHH], or [LLH] tonal melodies. The exception to this is a small number (less than 10\%) of words that have a so-called 'minor' tonal melody. These are described in Dumestre (1987:61, 2003: 23-24) and discussed further in Leben $(2002,2003)$ and Green $(2015)$; we consider a few loanwords that exhibit these melodies and the implications that they have for our analysis further below.

12 The distribution of these three melodies across the TBUs of trisyllabic words and in particular that of the LHH vs. LLH melodies has been argued to be largely predictable based on a combination of segmental (Dumestre 1987) and prosodic factors (Leben 2002, 2003; Green 2010, 2015). This means that the distinction between and distribution of LHH and LLH is not contrastive in trisyllabic words. Both Leben and Green have argued that the distribution of these melodies in trisyllabic words is the result of a version of the aforementioned affaissement process wherein Bambara's marked L tone (Creissels 2009; Creissels \& Grégoire 1993) spreads rightward across 
so-called 'weak' consonants within the prosodic domain known as the foot. Like others before us, we assume for now that Bambara exhibits binary feet, and we will return to further discussion of their characteristics and the distinction between 'weak' vs. 'strong' consonants in more detail below.

As we mentioned just above, Leben and Green have shown that affaissement within a foot is a natural, assimilatory tonal process that decreases the number of tonal contours within the foot domain. According to their accounts, the lexical, non-derived melody is /LHH/. They argue that this melody occurs in instances where a 'strong' consonant (i.e., an obstruent, except in one condition discussed below) is found in a foot-internal syllable onset. In two 'weak' conditions, however, the second tone of the sequence assimilates to the first, resulting in a [LLH] melody. This 'weak' outcome arises i) when a sonorant or glide occupies the onset of the second syllable of a foot; and ii) when a velar obstruent occupies the onset of the second syllable of a foot and is flanked by identical vowels (i.e., when $\mathrm{CV}_{\alpha} \mathrm{KV}_{\alpha}$, where $\mathrm{K}$ is a velar stop). ${ }^{2}$ The mechanism for affaissement and these two outcomes are schematized in (2). ${ }^{3}$

(2) $L$ tone spread within a foot

$$
\begin{array}{ll}
\text { /garaka/ } \rightarrow \text { (ga.ra)(ka) } \rightarrow \text { [gàràká] } & \begin{array}{l}
\text { 'to correct' } \\
\text { cf. [bùtúrú] 'large basket }
\end{array}
\end{array}
$$

b. velar obstruent context

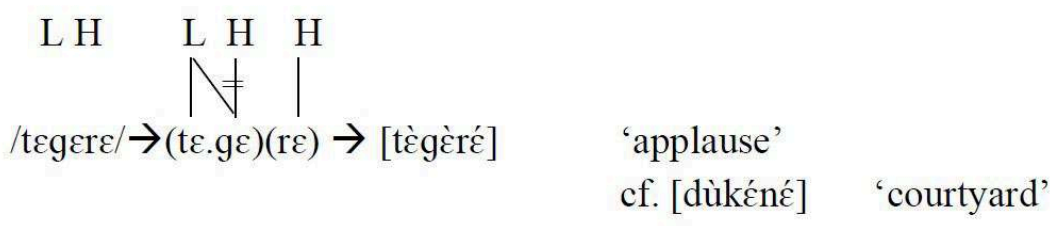

14 Representative examples are in (3) of Bambara trisyllabic words of non-Arabic origin in which affaissement occurs in the 'weak' context (3a-f) or does not occur in the 'strong' context (3g-k). ${ }^{4}$

(3) LLH vs. LHH melody in non-Arabic Bambara trisyllabic words

\begin{tabular}{|l|l|l|}
\hline & Bambara & Gloss \\
\hline a. & bàlàká & 'to hurry' \\
\hline b. & bùlùkú & 'to plow' \\
\hline c. & sàràbá & 'wick' \\
\hline d. & tììntí & 'to glide' \\
\hline e. & dègèmú & 'discourse' \\
\hline f. & sùgùré & 'sickness' \\
\hline
\end{tabular}




\begin{tabular}{|l|l|l|}
\hline & & \\
\hline g. & bùtúrú & 'large basket' \\
\hline h. & gèséré & 'type of griot' \\
\hline i. & tàsálí & 'to need to vomit' \\
\hline j. & fùnténí & 'heat' \\
\hline k. & kàkóló & 'ethnic group of Kaarta and Banamba that speak a Manding variety' \\
\hline
\end{tabular}

15 For the sake of comparison, we show in (4) that there is nothing unusual or unexpected about the distribution of the lexical $\mathrm{H}$ melody across trisyllabic monomorphemic Bambara words. Indeed, an all-H melody can be found associated with words matching both the 'weak' (4a-f) and 'strong' (4g-k) contexts described above.

\section{(4) $\mathrm{HHH}$ melody in Bambara trisyllabic words}

\begin{tabular}{|l|l|l|}
\hline & Bambara & Gloss \\
\hline a. & bálímá & 'sibling' \\
\hline b. & búrújú & 'origin' \\
\hline c. & fárítá & 'orphan' \\
\hline d. & kíríké & 'saddle' \\
\hline e. & sćgćrć & 'to rejoin' \\
\hline f. & fúgúlá & 'hat' \\
\hline & & \\
\hline g. & bútúrú & 'baby chicken' \\
\hline h. & díbírí & 'cone-shaped hat' \\
\hline i. & fúsúkú & 'small gift' \\
\hline j. & kásánké & 'shroud' \\
\hline k. & sćbćrć & 'spur' \\
\hline
\end{tabular}

The importance of invoking a distinction between 'strong' and 'weak' consonants in analyzing the $\mathrm{L}$ tone spreading of affaissement in trisyllabic words is (to our knowledge) first discussed in Dumestre (1987: 85-91), although without reference to foot structure. Dumestre draws a general distinction between 'weak' and 'strong' consonants in Bambara by dividing the language's consonants into four degrees of strength based 
almost entirely on manner of articulation. These degrees of consonant strength are summarized in (5).

(5) Degrees of Bambara consonant strength (adapted from Dumestre 1987:88)

\begin{tabular}{|l|l|l|}
\hline $1^{\text {st }}$ degree & strong & $/ \mathrm{p}, \mathrm{b}, \mathrm{t}, \mathrm{d}, \mathrm{d} 3, \mathrm{k}, \mathrm{g} /$ \\
\hline $2^{\text {nd }}$ degree & semi-strong & $/ \mathrm{f}, \mathrm{s}, \mathrm{S}, \mathrm{j}, \mathrm{w}, \mathrm{h} /$ \\
\hline $3^{\text {rd }}$ degree & semi-weak & $/ \mathrm{m}, \mathrm{n}, \mathrm{n} /$ \\
\hline $4^{\text {th }}$ degree & weak & $/ \mathrm{l}, \mathrm{r} /$ \\
\hline
\end{tabular}

17 In order to explain the effects of affaissement in trisyllabic words, Dumestre's analysis requires two rules. The premise of the first rule is that "in the majority of cases," LHH is the default tonal outcome for trisyllabic words when the onset of the second of three syllables is "strong," as in fitíri' dusk' andkòpóró'penny.' Dumestre himself places the word "strong" in quotation marks; however, we presume that his rule is meant to refer to both 1st degree "strong" and 2nd degree "semi-strong" consonants, as the examples that he offers in support of this rule include second syllable onset consonants from both of these proposed strength categories.

Exceptions to the first rule are said to be the result of a second rule. The second rule states that a LLH melody will be the expected result when the onset of the second of three syllables is "weak" (as in dòlòkî'shirt'); however, it will also result if the onset consonants of the second and third syllables belong to the same strength group (as in kàsàbí

'total,' but note that 's' and 'b' in fact belong to two different strength groups, according to Dumestre's categorization in (5)). The exception to the second rule, raised by Dumestre himself, is when vowels of the second and third syllables are identical to one another yet different from that in the first syllable, as in mànkútú to praise.'

In sum, Rule 1 requires evaluation of the strength of the second syllable onset only; Rule 2 instead must evaluate and compare the strength of both the second and third syllable onsets; and Rule 3 is different in that it must accomplish the evaluation and comparison of Rule 2 while subsequently evaluating the quality of all three vowels. Via these three rules, Dumestre's analysis accounts for approximately ninety percent of the trisyllabic word tonal melodies in his corpus. The remainder of the outcomes are attributed to i) other exceptions; ii) possible variation; and iii) in the case of certain borrowed words, the possibility that characteristics of the lending language may influence the resulting tonal melodies. Our goal in this paper is to explore this third possibility in more detail. More specifically, we aim to show that while the alternation between LHH and LLH melodies is predictable in most instances, there are no additional rules required to predict where words have deviated from the expected distribution of these melodic patterns. Rather, we illustrate that words that do not exhibit the expected distribution of these tonal melodies are borrowings whose structural characteristics are somehow incompatible with those permitted in Bambara. Moreover, we aim to show that the instances in which their distribution deviates from patterns in 
words of non-Arabic origin are principled, phonologically predictable, and related to properties of Bambara's prosodic structure.

As we illustrate below, we have reevaluated Dumestre's analysis by drawing not only on words analyzed in Dumestre (1987) but also similarly shaped words gathered from two commercially-available Bambara-French dictionaries (Bailleul 2007 and Dumestre 2011). We find (as did Dumestre) that in the vast majority of instances, the expected distribution of the LH tonal melody across trisyllabic words is [LLH] in the 'weak' second syllable context, while it is $[\mathrm{LHH}]$ in the 'strong' second syllable context. Unlike Dumestre, however, we aim to show that deviations from these patterns arise only in loanwords, rather than as the result of a series of rules. We illustrate that certain words borrowed into Bambara have unique phonological properties that affect the distribution of tonal melodies.

By considering the phonological behavior of Bambara words of non-Arabic origin vs. those identified as loanwords separately, we aim to arrive at a clearer generalization concerning the distribution of the tonal melodies associated with these words. We illustrate that when the shape of a borrowed word can be harmoniously accommodated by Bambara's prosodic structure, the borrowed word will be assigned a tonal melody according to the patterns established above for words of non-Arabic origin. However, when there are incompatibilities between the structure of the borrowed word and that permitted by Bambara's prosodic structure, a somewhat divergent tonal outcome arises. We show that our approach accurately predicts the appearance of these divergent outcomes with fewer outliers. Our approach also requires only a single rule whose outcome relies upon the nature of a foot-internal syllable onset. Rules requiring evaluation of vowel quality and more than two degrees of consonant strength are not necessary. ${ }^{5}$

With these preliminaries on Bambara tonology and an overview of earlier work concerning the distribution of tonal melodies in place, we turn next to discussing the characteristics of the language's prosodic structure in more detail.

\section{Prosodic structure}

Our discussion of prosodic structure references components or domains assumed in contemporary conceptions of Prosodic Hierarchy Theory (Hayes 1989; Nespor \& Vogel 1986; Selkirk 1978, 1984, 2011, among many others). The prosodic hierarchy, as its name implies, is organized such that one or more smaller units (e.g., syllables) comprise and are dominated by successively larger units (e.g., feet) and so forth, as schematized in (6). The foot and successively higher units have been referred to as domains, as they often act as a locus or domain of application for particular processes (Selkirk 1986, and references therein). As indicated in the figure, structural categories can be divided into two groups, namely rhythmic categories and interface categories (Ito \& Mester 2013). 


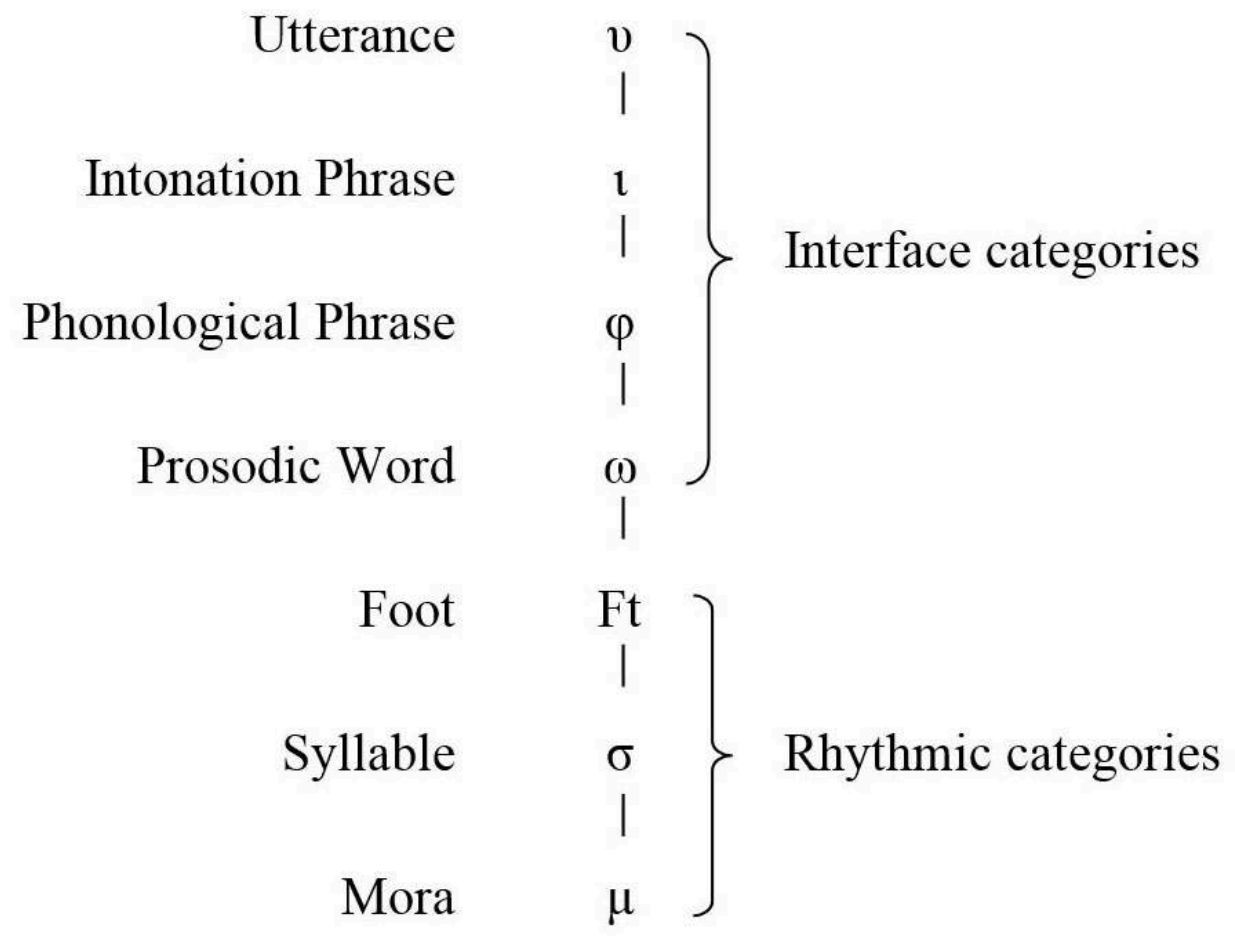

In this paper, the prosodic units with which we will be primarily concerned are the rhythmic categories, which often enter into analyses of meter, stress, prominence, and/or accent. In particular, we are concerned with the foot domain and the parameter of HEADEDNESS. The HEADEDNESS parameter, generally speaking, states that each prosodic domain has some constituent of the next smaller category that is designated as most prominent; this is the head of the domain. This parameter is one of four defining components of prosodic structure, the others being LAYEREDNESS, EXHAUSTIVITY, and NONRECURSIVITY (Selkirk 1984). Of these parameters, LAYEREDNESS and HEADEDNESS are understood to be inviolable (Selkirk 1996). Importantly, the inviolability of this parameter stipulates that every domain (and indeed every foot) must have a head. Headedness of the foot domain is invoked in the discussion of strong vs. weak syllables, although precisely what phonetic or phonological correlates constitute the notion of strong vs. weak is language-specific. It is typologically ideal for feet to be binary (whether moraic or syllabic), and feet are of two sorts: iambs and trochees. Iambs are weak+strong sequences, while trochees are strong+weak; the relatively stronger of the two positions is the head of the foot. It is typologically well-attested that iambic feet prefer to maintain an unbalanced, being weak+strong (Hayes 1985). Trochaic feet may in some languages be unbalanced; however, it is more common for them to be balanced (Prince 1991) with neither position exhibiting an overt metrical prominence.

Although it is generally agreed upon that the foot domain plays an important role in Bambara phonology (e.g., Bamba 1991; Green 2010, Leben 2002, 2003, Rialland \& Badjimé 1989; Weidman \& Rose 2006; Vydrine 2002, 2010, 2014), not all who have written on the subject agree on all characteristics of Bambara feet. Concerning the headedness of Bambara feet, there are two main perspectives, as explicated in Green 
$(2010,2015)$ and Vydrine $(2010,2014){ }^{6}{ }^{6}$ Both perspectives draw on evidence related to segmental reduction in support of their respective arguments. Green (2010) argues in favor of trochaic feet, while Vydrine (2010) appears to argue in favor of iambic feet. This viewpoint is later clarified in Vydrine (2014), in which he suggests that three types of feet are possible in the language: iambic, trochaic, and neutral. Vydrine (personal communication) explains that this analysis poses that footing specification in Bambara is lexical and that headedness is assigned to each foot of a given word. While there is perhaps not space to discuss both arguments in full detail here, we summarize them as follows.

In describing a more phonologically-conservative variety of Bambara than that discussed, for example, in Green (2010), Vydrine's analysis argues that instances of $($ CV.LV) $\rightarrow($ CLV) vowel deletion that occur in Bambara (where $\mathrm{L}$ is some liquid consonant) result only in iambic feet and are due to the fact the rightmost vowel in such an iambic foot is in a stronger foot position and is therefore less prone or immune to reduction. Words like màrìfá $\rightarrow$ [màrfá]

'gun,' however, in which the second syllable of the word is reduced, would have an initial trochaic foot whose head is immune to reduction. Finally, words for which no reduction occurs (like

bóló'arm') exhibit what he refers to as 'neutral' feet.

Green (2010) describes a 'colloquial' variety of Bambara spoken in Bamako, Mali, in which segmental deletions are more abundant. He discusses two segmental deletion processes that produce many of the same reduced outcomes possible in other Bambara varieties (e.g.,

$($ CV.LV $) \rightarrow($ CLV)); however, his data illustrate a wider variety of deletions in which ( CV.LV) $\rightarrow($ CVL

); this outcome is similar to the 'gun' example just above. Green argues that the types of deletions allowed in a given Bambara variety arise due to differing, variety-specific constraints on their phonotactics and metrical structure, rather than solely due to the metrical characteristics of headedness. More recently, Green (2015) suggests that while it is true that the prominent position of iambs should be largely immune from deletion (i.e., iambs prefer to be unbalanced (Hayes 1985), because trochaic feet generally prefer to be balanced and to minimize overt metrical prominence (Prince 1991), either position in a trochaic foot (including the head) could be eligible for deletion/reduction under the appropriate phonotactic conditions. For Green, reduction is not dependent solely on metrical conditions, but rather also by independent constraints affecting other components of the phonology. Moreover, and following from discussion in Martínez-Paricio (2013: 15) and Bennett (2012: 37), we expand upon this stance in suggesting that these properties imply that Bambara feet are stressless. Under this view, while a foot may be stressless such that either position of a stressless foot (including its head) can be reduced, the inviolable principle assumed in Prosodic Hierarchy Theory that every foot must have a head is still maintained. Indeed, Green (2015) illustrates that headedness and trochaicity more generally can be independently motivated in Bambara by other properties (e.g., segment distribution, segment co-occurrence restrictions, other segment reduction process, tone distribution, and by extension, other tonal processes such as compacité tonale). ${ }^{7}$ For these reasons, we assume that Bambara has trochaic feet that are bimoraic and maximally disyllabic, yet they do not exhibit properties of stress. 

istribution in many instances, in some trisyllabic borrowings, their distribution does not follow the same pattern found in Bambara words of non-Arabic origin. In most of these exceptional cases, a LLH melody arises where a LHH melody is expected. In just three instances that we have found, a LHH melody instead occurs when a LLH melody is expected. Viewed independent of other factors, these outcomes are somewhat puzzling because although the tonal melodies themselves occur throughout the lexicon, their distribution in borrowings is unlike that found elsewhere in the language. It may be that because the tonal melodies themselves are like those encountered elsewhere in the language, the phonological motivations underlying their unusual distribution in borrowed words have been mostly brushed aside. We aim to show, however, that the unusual distribution of these tones is due to phonological mismatches between Arabic and Bambara. More specifically, we will propose that the exceptional distribution of tonal melodies that we and others have observed has arisen due to Bambara's attempt to somehow maintain the prosodic prominence present in a given Arabic source word while remaining faithful to strict constraints on its own prosodic structure.

\section{Phonological mismatches between Bambara and Arabic}

In Section 2, we provided an overview of the characteristics of the Bambara tonal system as they relate to the language's distribution of lexical H and LH melodies across words of different shapes. While Bambara makes use of both lexical and grammatical tonal distinctions, Arabic is non-tonal. Despite this fact, during the loanword incorporation process, Arabic borrowings are assigned a $\mathrm{H}$ or LH tonal melody. The distribution of these melodies will be our main point of discussion.

In addition to an inherent tonal mismatch between Bambara and Arabic, there exists a prominence mismatch between the two languages. As stated above, we follow those before us (e.g., Zappa 2009, 2011) in assuming that Classical Arabic (CA) is an appropriate baseline upon which to base much of our discussion of Arabic loanword incorporation into Bambara. We also consider below what, if any, phonological role Soninke may have played as an intermediary language in the borrowing process.

Mandenkan, 56 | 2016 

stress is realized in one of several word positions, depending on the distribution of syllables within a given lexeme. The placement of stress is determined by the presence and location of heavy syllables (Watson 2011). Heavy syllables in Arabic include: i) an open syllable containing a long vowel (CV:); ii) a syllable closed by a single consonant (CVC); and iii) a syllable closed by the first element of a geminate (CVC:). In addition, Arabic permits superheavy syllables in some instances. General principles of Arabic stress assignment are summarized in (7).

(7) Stress assignment in Classical Arabic - summarized from Watson (2011)

i) stress a final superheavy syllable;

ii) otherwise, stress a heavy penult;

iii) otherwise, stress the antepenult

Few studies that we are aware of explore the phonetic correlates of Arabic stress. Of those that we have seen, Al-Ani (1992) found that fundamental frequency (pitch), vowel duration, and intensity are all enhanced in stressed syllables. De Jong and Zawaydeh (1999) built upon Al-Ani's findings, illustrating the degree to which higher fundamental frequency and increased vowel duration are correlates of stress, at least in Ammani-Jordanian Arabic.

In contrast, there are no known phonetic studies establishing phonetic correlates of stress in Bambara. In fact, stress appears not to be an attribute of Bambara's phonology. While it has been shown that Bambara avoids the creation of iambic (weak+strong) sequences as the result of certain syllable reduction processes (e.g., Green 2010, 2015; Green, Davis, Diakite \& Baertsch 2014), the fact that Bambara permits vowel deletion in either position of a foot under amenable phonotactic conditions suggests that stress is not necessarily a property of the head of a foot in this language. Headedness, however, is expressed in other ways. For example, these works show that Bambara accommodates prominence in the form of syllabic complexity (i.e., syllables with complex onsets or long vowels) only in foot-initial positions. Still other characteristics that we discussed above point toward the language's prosodic system being built upon trochaic footing.

The most apparent mismatches between Bambara and Arabic, however, are those resulting from the fact that the Arabic consonant inventory is more complex than that of Bambara. Arabic consonants that have no phonological equivalent in Bambara include emphatics $\left(b\left[\delta^{\mathrm{i}}\right], b\left[\mathrm{t}^{\mathrm{i}}\right], ض\left[\mathrm{~d}^{\mathrm{i}}\right], \boldsymbol{\omega}\left[\mathrm{s}^{\mathrm{s}}\right]\right)$, pharyngeals ( $\left.[\mathrm{H}]\right)$, uvulars (ق $\left.[\mathrm{q}], \dot{\varepsilon}[\mathrm{b}]\right)$,

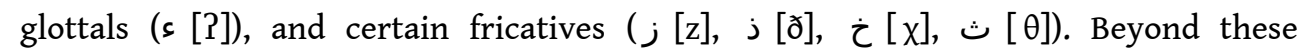
incompatible Arabic consonants, some African varieties of Arabic that may also have contributed to Bambara contain additional emphatic consonants. For example, Hassaniya Arabic (spoken widely in what is now neighboring Mauritania) contains $\mathrm{r}^{\mathrm{s}}$, $\mathrm{b}^{\mathrm{S}}, \mathrm{m}^{\mathrm{i}}, \mathrm{n}^{\mathrm{\complement}}, \mathrm{v}^{\mathrm{i}}$, and $\mathrm{l}^{\mathrm{f}}$. Likewise, some African varieties of Arabic may lack particular consonants found in CA. For comparison, the consonant inventories of the two languages are given in (8) and (9), respectively. Marginal Bambara phonemes are indicated in (9) by <>. 
(8) CA consonant inventory - adapted from Watson (2002:13)

\begin{tabular}{|c|c|c|c|c|c|c|c|c|c|}
\hline & Labial & $\begin{array}{l}\text { Labio- } \\
\text { dental }\end{array}$ & Dental & Alveolar & $\begin{array}{l}\text { Post- } \\
\text { alveolar }\end{array}$ & Velar & Uvular & Pharyngeal & Glottal \\
\hline Plosive & $b$ & & & $\mathrm{t}, \mathrm{d}$ & & k & $q$ & & ? \\
\hline emphatic & & & & $\mathrm{t}^{\mathrm{s}}, \mathrm{d}^{\mathrm{s}}$ & & & & & \\
\hline Fricative & & $f$ & $\theta$, , & $\mathrm{s}, \mathrm{z}$ & s & & $x$, , & $\mathrm{H}, \mathrm{S}$ & $h$ \\
\hline emphatic & & & $\delta^{\mathrm{q}}$ & $s^{s}$ & & & & & \\
\hline Affricate & & & & & d3 & & & & \\
\hline Nasal & $\mathrm{m}$ & & & n & & & & & \\
\hline Lateral & & & & 1 & & & & & \\
\hline Rhotic & & & & $\mathrm{r}, \mathrm{\Gamma}$ & & & & & \\
\hline Glide & w & & & & $\mathrm{j}$ & & & & \\
\hline
\end{tabular}

(9) Bambara consonant inventory - adapted from Dumestre (2003:15)

\begin{tabular}{|l|l|l|l|l|l|l|}
\hline & Labial & Labio-dental & Alveolar & Post-alveolar & Velar & Glottal \\
\hline Plosive & $\mathrm{p}, \mathrm{b}$ & & $\mathrm{t}, \mathrm{d}$ & & $\mathrm{g}, \mathrm{g}^{\mathrm{w}}, \mathrm{k}$ & \\
\hline Fricative & & $\mathrm{f}$ & $\mathrm{s},<\mathrm{z}>$ & $<\mathrm{s}$ & & $\mathrm{h}$ \\
\hline Affricate & & & & $\mathrm{t} \int \mathrm{d} 3$ & & \\
\hline Nasal & $\mathrm{m}$ & & $\mathrm{n}$ & $\mathrm{n}$ & $\mathrm{y}$ & \\
\hline Lateral & & & $\mathrm{l}$ & & & \\
\hline Rhotic & & & $\mathrm{r}$ & & & \\
\hline Glide & $\mathrm{w}$ & & & $\mathrm{j}$ & & \\
\hline
\end{tabular}

Besides resolving these segmental mismatches, there are other phonotactic incompatibilities whose resolution appears to be fairly uncontroversial in most cases. Among these are the simplification of geminate consonants and the resolution of disallowed constituents in syllable margins, such as consonant clusters and word-final codas. In addition, it is most common for input long vowels in Arabic words to be shortened in the loanword incorporation process. Somewhat surprisingly, this tends to occur regardless of the position of the vowel with the word. We will have more to say about this below. Having compared the structural and prosodic characteristics of 
Bambara and Arabic, we turn our attention next to the tone patterns associated with Arabic loans in Bambara.

\section{Tone patterns in Arabic loans}

There are many words of Arabic origin in Bambara, most of which stem from the realms of religion and commerce. These words have been borrowed, adapted, and have long since been incorporated into the Bambara lexicon. There has been fairly little attention paid to these words in the Bambara tonology literature, perhaps because their surface tonal melodies do not, at first glance, appear to be overtly exceptional. As we illustrate below, however, in some instances their melodies differ in notable ways from that of similarly shaped Bambara words of non-Arabic origin.

The vast majority of the examples given below are drawn from a small corpus of Arabic loans into Bambara that we have compiled from Bailleul (2007) and Dumestre (2011); these are two commercially available Bambara-French dictionaries that include tone marking. Additional examples are drawn from Dumestre (1987) and are provided for the sake of comparison. The words in our corpus were extracted by hand from the two aforementioned dictionaries based on the indications provided by the respective authors of the dictionaries that a particular word is derived from Arabic. There may, of course, be other words in these sources that are arguably derived from Arabic, but we based our study on only those words overtly tagged as Arabic borrowings. In a number of instances, the authors of these dictionaries provide a specific form of a given Arabic word that they suggest is the origin of the borrowing. We assume these same forms where they have been provided; however, we have endeavored to match part of speech between corresponding forms in order to arrive at a more principled comparison between the input and output of the incorporation process. In those instances in which we encountered a part of speech mismatch between the Bambara entry and the purported Arabic input word, we consulted Arabic-English dictionaries of both Classical (Lane 1863) and Modern Standard Arabic (Cowan 1994) to determine if a more appropriate source form from the same root could be identified and might be appropriate by extension.

In total, the corpus upon which we base our observations contains 213 words, 47 (22\%) of which are tonally exceptional; that is, their tonal melodies differ from those found associated with Bambara words of non-Arabic origin of the same size and shape. Although this may seem like a fairly small corpus, we find that our corpus is nearly identical in size to that upon which Dumestre (1987: 86) based his observations about Arabic borrowings into Bambara ("approximately 200 words"). The French to English translations that we include are our own. Some Arabic equivalents are drawn from Cowan (1994) and Lane (1863), and a Romanization of the Perso-Arabic script for Arabic equivalents is also provided. Long vowels in Arabic are indicated in the Romanization by a macron over the vowel, e.g. $\bar{a}$, and an underdot indicates an emphatic consonant, e.g., d.

\subsection{Overview}

41 Upon entering the Bambara lexicon, one part of the loanword adaptation process involves the assignment of one of Bambara's two basic tonal melodies ( $\mathrm{H}$ or $\mathrm{LH}$ ) to a 
lexeme. Again, as we discussed above, our analysis assumes an assimiliationist viewpoint of Bambara tonology. In surveying our corpus of borrowings, we find no evidence to suggest that the assignment of one tonal melody vs. the other is conditioned by a particular property, feature, or part of speech of a given lexeme, nor by the initial consonant of the word. That is, we believe that the assignment of a $\mathrm{H}$ or LH tonal melody to a loanword entering Bambara from Arabic is unpredictable, just as it is for Bambara words of non-Arabic origin. We illustrate this in (10) where Arabic borrowings of similar shapes and segmental makeup are associated with one or the other tonal melody.

(10) H vs. LH melody in Arabic borrowings

\begin{tabular}{|c|c|c|c|c|}
\hline & Bambara & Gloss & & \\
\hline a. & bàlàká & to rush ahead & balaqa & بَلَقق \\
\hline b. & báríká & benediction & baraka & بَرَكَة \\
\hline c. & fitírí & dusk & fițr & رطْف \\
\hline d. & fítíné & quarrel & fitna & فِتْنَة \\
\hline e. & jànàjá & burial & ğanāza & جَنازَة \\
\hline f. & jáhílí & ignorant & ğāhil & هِلاج \\
\hline g. & kàràmá & respect & karam & كَرَم \\
\hline h. & kárábá & to force & karaba & كَرَبَ \\
\hline
\end{tabular}

In the remainder of this section, we will first show that many Arabic borrowings into Bambara do in fact maintain one of the predictable patterns of tonal melody assignment that one finds in Bambara words of non-Arabic origin, such as those introduced in (3) and (4). We then turn to discussing those instances in which the assignment of tonal melodies in some Arabic borrowings diverges from the norm.

Despite their tonal outcomes being unproblematic, we begin by showing that the borrowed words in (11) exhibit an all-H melody in both 'weak' (11a-f) and 'strong' (11g-l) contexts; this outcome matches that found in the Bambara words of non-Arabic origin.

\section{(11) HHH melody in Arabic borrowings}

\begin{tabular}{|l|l|l|l|l|}
\hline & Bambara & Gloss & & \\
\hline a. & báwúlí & urine & bawl & بَوْ \\
\hline
\end{tabular}




\begin{tabular}{|c|c|c|c|c|}
\hline b. & dárájá & influence & darağa & جَةرَدَ \\
\hline c. & dórómé & money & dirham & هَم:-َ:ْرد \\
\hline d. & háwújá & distress & ḥawğ & حَوْْج \\
\hline e. & jáhílí & ignorant & ğāhil & جاهِل \\
\hline f. & hádíyá & guide & hādī & هادي \\
\hline g. & hákílí & thought & Eaql & عَقْل \\
\hline h. & hásídí & jealousy & ḥasad & حَسَد \\
\hline i. & káfírí & infidel & kāfir & كافِر \\
\hline j. & sábálí & patience & șabr & صَبْر \\
\hline $\mathrm{k}$. & síbírí & Saturday (sabbath) & sabata & سَبَتَ \\
\hline 1. & táríkí & history & tārī $\chi$ & يختار \\
\hline
\end{tabular}

As in Bambara words of non-Arabic origin, the situation is more complex in trisyllabic Arabic borrowings that have been assigned a lexical LH tonal melody. In many instances, we find that the tonal patterns of trisyllabic Arabic borrowings will exhibit a distribution of LLH vs. LHH melodies in 'weak' vs. 'strong' contexts, respectively, that is in line with that of Bambara words of non-Arabic origin. That is, a LLH melody is found when the onset of the second syllable of the word is a 'weak' consonant, similar to that described and schematized in (2). Likewise, a LHH melody is found when the onset of a second syllable is a 'strong' consonant. We show examples of these outcomes in for 'weak' (12a-e) and 'strong' (12f-j) contexts.

An unproblematic distribution of the LLH vs. LHH melodies results in many instances, but we also come across exceptions that must be explained. For example, we show in (13) those few instances in which a LHH $\rightarrow$ LLH alternation does not occur in a 'weak' consonant context (13a-c); these are the only three instances in our corpus where this exception arises. We then show that a LHH $\rightarrow$ LLH alternation occurs where it should not have, namely in a 'strong' context, in (13d-j). This is the exceptional outcome observed most frequently in our corpus.

(12) Predicted distribution of LLH vs. LHH in trisyllabic borrowings

\begin{tabular}{|l|l|l|l|l|}
\hline & Bambara & Gloss & & \\
\hline a. & bàlikú & adult & bālig & بَالغ \\
\hline b. & bàriká & force, vigor & baraka & خَدَّاعَ' \\
\hline c. & hàràkí & cheater & haddāe & \\
\hline
\end{tabular}




\begin{tabular}{|c|c|c|c|c|}
\hline d. & jàràbí & passion & durba & 8ُدربَة \\
\hline e & sìlàmé & Muslim & muslim & مُسْلِم \\
\hline f. & fiotíní & dusk & fițr & رطُفِ \\
\hline g. & jàbárú & majesty & jabr & جَبْر \\
\hline h. & kàfárí & to atone for & kaffara & رَّن \\
\hline i. & misírí & mosque & masjid & مَسْجِد \\
\hline j. & sàfíné & soap & șābūn & صابون \\
\hline
\end{tabular}

\section{(13) Exceptional distribution of LLH vs. LHH in trisyllabic borrowings}

\begin{tabular}{|c|c|c|c|c|}
\hline & Bambara & Gloss & & \\
\hline a. & biláyí & 'by God' & bi-llāhi & مِأللهِ \\
\hline b. & kùráné & 'Quran' & qur'ān & قُرْآن \\
\hline c. & màkámá & 'glory, renown' & maqāma & مَقامَة \\
\hline d. & dùgàwú & 'benediction' & ducā' & دُعاء \\
\hline e. & gètèré & 'mercenary' & qāṭic & قاطع \\
\hline f. & hìdàyá & 'begging' & hadāyā & ياهدا \\
\hline g. & kàbàrú & 'genuflection' & kabbara & كَبَّرَ \\
\hline h. & kibirí & 'sulfur' & kibrìt & بْرِيت \\
\hline i. & kitàbú & 'book' & kitāb & كِتاب \\
\hline j. & kùtùbá & 'sermon' & xutba & خُطْبَة \\
\hline
\end{tabular}

It is commonplace for loanwords to exhibit certain unique characteristics compared to other non-borrowed words in the language, yet it is surprising from a prosodic perspective that the well-established and typologically predicted patterns of loanword tonal melody assignment discussed in Kang (2010) appear to be ignored in these and similar words in Bambara. That is, while it is typologically most common for a borrowing language to preserve and maintain the assignment of suprasegmental characteristics such as tone patterns via native mechanisms, something else appears to occur in Arabic loanword incorporation into Bambara. In the sections below, we discuss 
possible explanations for how and why these exceptions have come to be, as well as how and why they may have managed to persist in Bambara.

\subsection{Possible influences of prosodic structure}

47 In order to explore possible explanations for the disparity between Arabic loans of the type shown in (13) and word of non-Arabic origin of similar sizes and shapes, we searched our corpus of Arabic borrowings into Bambara for the prosodic composition of the Arabic source words. In looking at the probable Arabic inputs, we found that words with exceptional surface tonal melodies are from source words that can be divided into two main classes, as shown in (14) and (15). These two classes can be differentiated from one another based on the syllabic structure of the source words and, thereby, according to their patterns of metrical prominence as evaluated by the principles for Arabic stress assignment defined in (7). According to these principles, the source Arabic words in these classes have a metrical prominence either on their final syllable (in the case of disyllabic words) or their penultimate syllable (in the case of trisyllabic words); this is as one would expect in a prosodic system like Arabic's that is built upon iambic feet. For reasons outlined above, we assume that Bambara's prosodic system is built upon trochaic feet parsed from left to right. As such, the location of the metrical prominence in the aforementioned source Arabic words does not match what is otherwise accommodated by Bambara's prosodic system. If Bambara were to maintain these same prominences found in these Arabic source words, the result would be the creation of iambic sequences, which other research has shown are otherwise avoided in Bambara.

In (14), each disyllabic Arabic source word has a stressed, superheavy final syllable. The corresponding borrowing in Bambara has only short, open syllables. The adaptation made (vowel shortening and final epenthesis) are necessary in order to bring the words in line with Bambara's fairly strict maximal CV syllable template. It should be clear that the iambic prominence of the source word is not metrically (i.e., durationally) maintained in the Bambara borrowing. What we find interesting, however, is that the syllable corresponding to what would have been the stressed position of the source word (i.e., the second syllable of both the source word and borrowed word) is associated with a $\mathrm{L}$ tone. The presence of this $\mathrm{L}$ tone is arguably unexpected. This is owing to the fact that we have seen elsewhere that in Bambara words of non-Arabic origin, the second syllable of a trisyllabic word with a so-called 'strong' onset will typically have a $\mathrm{H}$ tone. Thus, the surface tonal melody in these Arabic borrowings is LLH while it is LHH in words of non-Arabic origin of the same size and shape. An analogous outcome is found in the borrowings in (15), where each trisyllabic Arabic source word has a penultimate stress that cannot be accommodated by Bambara's prosodic system. Once again, the location of the stressed syllable in the source word (again the second syllable of both the source word and borrowed word) is associated with a L tone, despite this syllable have a 'strong' onset. Like in (14), the words in (15) have a LLH melody where words of non-Arabic origin of similar shapes and sizes have a LHH melody. 
(14) Class 1: Disyllabic source words with a stressed superheavy final syllable

\begin{tabular}{|c|c|c|c|c|}
\hline & Bambara & Gloss & Arabic & \\
\hline a. & jènz̀yá & 'adultery' & zinā' & زناء \\
\hline b. & dùgàwú & 'benediction' & ducā' & دُعاء \\
\hline c. & hijàbú & 'divine protection' & hịāb & حِجاب \\
\hline d. & kàbùsí & 'pistol' & kabūs & كَبوس \\
\hline e. & kitàbú & 'book' & kitāb & كِتاب \\
\hline f. & sàbàrá & 'shoe' & șabbāṭ & اطون:-ضَب \\
\hline g. & wàkilú & 'witness' & wakîl & وَكيل | \\
\hline h. & mìsàlí & 'example' & mițāl & مِثال \\
\hline i. & sàbàtí & 'to prosper' & tabāt & تَبَات \\
\hline j. & tùbàbú & 'doctor' & țabīb & طَبيب \\
\hline k. & kibiríi & 'sulfur' & kibrīt & كِبْريت \\
\hline 1 & kàfàrá & 'forgiveness' & ḡufrān & غُفْران \\
\hline $\mathrm{m}$. & mùsàká & 'expense' & muskān & مُسْكان \\
\hline n. & kغ̀mèsú & 'pair of scissors' & miqāșṣ9 & مِقاصّ | مِ \\
\hline
\end{tabular}

(15) Class 2: Trisyllabic source words with a heavy, stressed penult

\begin{tabular}{|c|c|c|c|c|}
\hline & Bambara & Gloss & $\underline{\text { Arabic }}$ & \\
\hline a. & bàtàkí & 'correspondence' & bițāqa & بِطاقَة \\
\hline b. & màsibá & 'catastrophe' & mușība & مُصيبَة \\
\hline c. & tàbiyá & 'values of society' & țabīea & طَبيعَة \\
\hline d. & hidàyá & 'begging' & hadāyā & ياهَدا \\
\hline e. & jàmàná & 'country' & jamāea & ماعَةَنَج \\
\hline f. & tàmàkí & 'restraint' & tamakkun & تَمَكَّن \\
\hline
\end{tabular}

The surface LLH tonal melodies of borrowed words like those in (14) and (15) are clearly unlike those melodies found in the 'strong' context elsewhere in Bambara, but the reason that this outcome arises is yet unclear. Generally speaking, this outcomes 
appears to be somewhat counterintuitive given that a reported phonetic correlate of Arabic stress is an increase in pitch (Al-Ani 1992; de Jong \& Zawaydeh 1999), yet the exceptional melodies associated with these borrowings are well-attested in the literature.

One possible way to account for such melodies is to appeal to the properties and behavior of $\mathrm{L}$ tone elsewhere in the grammar. For example, $\mathrm{L}$ tone has been shown to be marked in Bambara and in other Manding languages (e.g., Creissels \& Grégoire 1993; Creissels 2009), and research has shown that the lexical distribution of $\mathrm{L}$ tone in these languages is restricted to perceptually and phonologically prominent word-initial and foot-initial positions (Green 2015). These prominent positions have also historically been the only positions that permit heavy (i.e., bimoraic) CVV or CVN syllables (Creissels 2009; Dumestre 2011). ${ }^{10}$ With these thoughts in mind, one could argue that in incorporating Arabic words with iambic prominences into the lexicon, Bambara speakers came to realize the prominent, stressed position of the source word with a $\mathrm{L}$ tone. As we mention above, this tone itself is marked and limited in its distribution to prominent foot-initial positions in words of non-Arabic origin. These exceptional patterns would then have eventually become lexicalized.

51 Such an outcome is not without precedent. As discussed in Kenstowicz (2007), a borrowing language may adopt a pattern of prosodic adaptation based on "relative auditory similarity" to a source word. Against the backdrop of Arabic-to-Bambara situation, Kenstowicz's Prosodic Prominence hierarchy suggests to us that if a language cannot faithfully accommodate prominence in its original position, then the next best option would be to substitute a native-like prominence, rather than ignoring the presence of the source prominence altogether. If this approach is correct, then it would suggest that, in the loanword incorporation process between Arabic and Bambara, despite the fact that an overt metrical prominence (i.e., vowel length) does not persist, the borrowing language attempts to remain as faithful as possible to the source prosodic prominence by equating the prominent source position with the next best option, namely a $\mathrm{L}$ tone. As we have seen, this occurs at the expense of a quasi-marked surface tonal melody in the borrowing language; we call this a quasi-marked tonal melody because the melody is not unique to loanwords, yet its distribution is unlike that found in non-borrowed words elsewhere in the lexicon. Such an effect would reveal a competition between faithfulness to segmental, syllabic, and suprasegmental properties of Arabic alongside well-formedness restrictions inherent in Bambara phonotactics and prosodic structure.

52 A second alternative offered by a reviewer is that the LLH melody found in the Arabic borrowings like those in (14) and (15) is due to this melody being the 'default' or perhaps most frequent melody for trisyllabic words. This point of view would align with the dissimilationist perspective on Bambara tonology that assumes that a /LLH/ melody alternates to $[\mathrm{LHH}]$ under some conditions. While we have already laid out our arguments above in favor of the assimilationist perspective on Bambara tone assignment, we also contend that this alternative would fail to provide an explanation for the many instances of an otherwise Bambara-like distribution of LLH vs. LHH melodies in Arabic borrowings in words like those presented in (12). That is, this approach would need to explain how and why words with a LHH melody would arise as a result of a non-morphological dissimilation across 'strong' consonants rather than by a natural process of tonal assimilation across 'weak' consonants within a foot. 

footing process is simply different in loanword adaptation, compared to footing in Bambara words of non-Arabic origin. That is, rather than foot assignment being left-to-right and creating trochees, as Green (2015) proposed for non-Arabic words, perhaps the footing process for Arabic loans instead begins (or is restarted) at the prominent input syllable. This alternative could be represented as in (16).

(16) Possible alternative footing for Arabic loanwords

$$
\begin{aligned}
& \text { L H L L H } \\
& \text { | | | } \\
& \text { حجاب haijāb/ }
\end{aligned}
$$

Even if this alternative footing were possible, the tonal melody associated with it would be unprecedented. A $(\sigma)(\sigma \sigma)$ footing pattern is certainly possible in Bambara, but it is found only in limited instances, such as in derivational operations involving prefixation by lá- or mă-. In such instances, however, LLH is never an attested tonal melody. Indeed, the possible tonal melodies resulting from lá- prefixation to $\mathrm{LH}$ or $\mathrm{H}$ disyllabic words are $(\mathrm{H})(\mathrm{LH})$ and $(\mathrm{H})(\mathrm{HH})$, respectively. Likewise, possible melodies resulting from mǎ- prefixation to similar disyllabic words are $(\overparen{\mathrm{LH}})(\mathrm{LH})$ and $(\mathrm{L})(\mathrm{HH})$, respectively. Thus, even if this alternative 'loanword footing' resulted in the first syllable of an input being footed on its own and subsequently being assigned a 'low' tonal melody, the expected outcome would be *(hî)(jàbú), which of course is unattested.

It might also be the case that if the marked L tone of the lexical LH melody simply associates with the prominent syllable of the input, it would result in the initial syllable of the word being left tonally underspecified. Were this to occur, we might expect this syllable to then receive a $\mathrm{H}$ tone by default; this is what occurs for tonally unspecified TBUs elsewhere in Bambara. This does not occur (we do not find *(hí)(jàbú)), and there is certainly no precedent in Bambara for a tonally unspecified TBU to receive a $\mathrm{L}$ tone.

One way to test this alternative footing further would be to test the behavior of exceptional LLH words like hìjàbú in a phrasal context containing a following $\mathrm{H}$ word. If footing is in fact $(\mathrm{L})(\mathrm{LH})$, we would expect to find $\mathrm{L}$ tone spreading via affaissement within the final foot, i.e. $(\mathrm{L})(\mathrm{LH}) \# \#(\mathrm{H}) \rightarrow(\mathrm{L})(\mathrm{LL}) \# \#(\mathrm{H})$. This possibility must await further field research.

these three alternatives, we believe that the first option brings about the fewest unfavorable implications. That is, while the second possibility outlined above necessitates the proposition of a phonetically unnatural tonal process and requires assumptions to be made about what qualifies as the 'default' distribution of the LH tonal melody, and the third possibility brings about incorrect predictions about possible tonal melodies in Bambara, the first option is better in line with other well-established properties of Bambara phonology. Overall, the first approach predicts that, rather than accommodating marked or otherwise unusual foot structures, Bambara remains as faithful as possible to the location of source prominence, despite the creation of quasi markedness in the surface tonal melodies of some words. In adopting such an approach, Bambara still obeys constraints on its own prosodic structure while distributing tonal melodies on Arabic borrowings that differ only minimally from those found elsewhere in the lexicon. 


\subsection{Segmental and syllabic prominence}

(17) Class 3: input disyllabic words with penultimate stress

\begin{tabular}{|c|c|c|c|c|}
\hline & Bambara & Gloss & & \\
\hline a. & dùgàrén & 'mirror' & șuwar & ل11 صُوَر \\
\hline b. & kibàrú & 'news' & xabar & خَبَر \\
\hline c. & kùtùbá & 'sermon' & xuṭba & خُطْبَة \\
\hline d. & gètèré & 'mercenary' & qāțiદ & قاطع \\
\hline e. & kàbàrú & 'prayer posture' & qabr & قَبْر \\
\hline f. & kàsàbí & 'amount' & kasb & كَسْب \\
\hline g. & tàsàlén ${ }^{12}$ & 'kettle' & țāsa & طاسَة \\
\hline
\end{tabular}

The examples described throughout Section 5.2 cover the vast majority of those Arabic borrowings that have what we have defined as exceptional tonal patterns. There are, however, a small number of other words whose tonal patterns are also exceptional but cannot be attributed to the precisely same characteristics. These comprise another small class of words derived from disyllabic Arabic source words that do not have a stressed superheavy final syllable. Recall from that if a disyllabic Arabic word does not have a superheavy final syllable, the penult receives stress instead. While we might expect these words to be accommodated readily into Bambara's trochaic prosodic structure with minimal adaptation, the tonal melodies of the borrowed words in (17) illustrate that this is not the case. Rather, it appears that either segmental or some other prominence related to syllable structure has a role to play in the assignment of the words' tonal melodies.

Although these words are few, certain shared details about them stand out. First, (17a-d) have initial syllables with either an emphatic or uvular consonant, both of which are incompatible with the Bambara sound inventory. (17c) also contains an emphatic consonant in the coda position of its initial syllable. The second syllable of (17d) begins with an emphatic consonant, while (17e-f) contain a complex coda. All of these characteristics are incompatible with Bambara's permitted inventory of consonants and/or syllable phonotactics. The outcome of $(17 \mathrm{~g})$ is more complex, but its segmental composition may play a role in the way that it has been adapted. The outcome in words whose input contains a geminate follows in a straightforward way given the principles outlined in Section 5.2. While heavy CV: syllables are historically accommodated in word-initial positions in Bambara, syllables with geminate consonants have no historical counterpart. We believe that, by extension, these non-native syllabic prominences were adapted in an analogous, although not identical way to the words in (14) and (15). The remaining outliers appear to have received their exceptional tonal melodies by a slightly different means which may have to do with emphatic and uvular consonants themselves exerting a marked depressor effect on the 
second syllable of the resulting words. The generalization here is that while prosodic prominence plays the primary role in the loanword incorporation process, segmental prominences also play a secondary role in some instances.

\subsection{Another look at unexceptional forms}

60 As was exemplified in (11) and (12), many trisyllabic Arabic loanwords in Bambara have tonal melodies whose distribution is identical to that of Bambara words of non-Arabic origin. That is, for these and similar words, the distribution of HHH, LHH, and LLH tonal melodies follows a predictable distribution in line with that discussed elsewhere in the literature. This includes the distribution of LHH vs. LLH tonal melodies in 'strong' vs. 'weak' contexts, respectively. Examples of such words are in (18).

(18) Trisyllabic Arabic borrowings with unexceptional tonal melodies

\begin{tabular}{|c|c|c|c|c|}
\hline & Bambara & Gloss & & \\
\hline a. & bàrìká & 'vigor' & baraka & بَرَكَة | \\
\hline b. & hàlàkí & 'to perish' & halaka & هَلَكَ \\
\hline c. & jàràbí & 'passion' & durba & 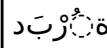 \\
\hline d. & síbírí & 'Saturday' & sabata & سَبَبَت \\
\hline e. & sùtúrá & 'to hide' & satara & سَتَرَ \\
\hline f. & nàgàsí & 'to ruin' & naqașa & نَقَصنَ \\
\hline g. & kálúwá & 'retreat' & xalwa & وَةلََّْ \\
\hline h. & màrifá & 'rifle' & midfac & مِدْفَع \\
\hline i. & misírí & 'mosque' & masjid & مَسْجِد \\
\hline j. & bàlikú & 'adult' & bāliḡ & بالغ \\
\hline k. & hákílí & 'intelligent' & āeqil & عاقِل | عِ \\
\hline 1. & jáhílíi & 'ignorant' & ğāhil & جاهِل \\
\hline $\mathrm{m}$. & nàbílá & 'prophet' & nabi $\bar{i}^{2}$ & نَبِيّ | \\
\hline n. & sàfinć & 'soap' & șābūn & صابون \\
\hline o. & jùrùmú & 'sin’ & jurm & جُرْم \\
\hline
\end{tabular}

Examples (18a-f) are derived from trisyllabic Arabic words that lack a heavy syllable; thus, these inputs have antepenultimate stress. For these inputs, there are no overt phonotactic or prosodic adaptations to be made, and therefore they are readily 
accommodated by Bambara's foot structure. Examples (18g-m) are different in that they are disyllabic Arabic inputs that have penultimate, word-initial stress. These words are also easily incorporated into Bambara with minimal adaptation; the location of their prosodic prominence is not at odds with the permitted foot structure. ${ }^{13}$ While it is true that these words do not behave exceptionally in terms of tonal melody assignment, some of them do exhibit a puzzling characteristic. More specifically, a reviewer asks us to comment on words like $(18 \mathrm{j}, \mathrm{k}, \mathrm{l}, \mathrm{n})$ whose corresponding inputs contain a word-initial long vowel. The reviewer wonders why if long vowels are (at least historically) accommodated by Bambara in word-initial position, the word-initial long vowels of these input words are shortened despite the fact that they appear in what we have argued is the left-edge, head position of a trochee. Although we cannot say for certain, one possibility is that although long vowels are/have been accommodated in this position, they are not necessarily ideal. As discussed earlier in this paper, several scholars have noted that long vowels are disappearing or are synchronically absent in the phonologies of some Bambara speakers, except in monosyllabic words. This might suggest that they are generally dispreferred in the language. This could be tied to a preference in Bambara for disyllabic trochees over monosyllabic (bimoraic) trochees. Yet another possibility might be that if bimoraic trochees are not necessarily dispreferred, incorporating Arabic loans with an initial long vowel would force a (CV:)(CVCV) parse which is itself an uncommon word shape in Bambara. Given the choice in loanword incorporation, Bambara may simply be opting to satisfy one of these preferences, where it can. We believe that the key generalization is that because the sources of loanwords like those in (18) do not exhibit a prominence in a location that conflicts with what is permitted in Bambara, they are able to accommodate a native pattern of tonal melody distribution. This supports our assertion that the location of the prominence in a source is the primary factor contributing to the presence of exceptional tonal melodies observed in Arabic loanwords.

As we mention above, there is some evidence suggesting that the exceptional patterns discussed above are unstable and may be in the process of being leveled out in favor of non-exceptional patterns in the synchronic form of Bambara phonology. During the compilation of our Arabic loanword corpus, we encountered several instances in which Bailleul (2007) and Dumestre (2011) provide opposing tonal patterns for borrowed words. Some examples are given in (19). In each case, one author provided the exceptional tonal melody, while the other included the non-exceptional melody. Dumestre (1987: 92) also points out a number of instances where he observed variation in similarly shaped words. In addition, there are also differences in some cases between the melody reported in Dumestre (1987) and that reported in Dumestre (2011). In any case, we believe this to be preliminary evidence that the marked melodic pattern may be in the process of resolving itself in the direction of the unmarked melody. This outcome is precisely what one might expect from the perspective of learnability. That is, over time, Bambara learners come to reanalyze exceptional yet non-contrastive patterns in the direction of expected patterns of tonal melody distribution. A slightly different perspective is provided in Kenstowicz (2007) who argues that the regularization of exceptional borrowing patterns tends to occur when the source (i.e., the reason for the exception) is no longer recognizable or salient to speakers.

(19) Variation and/or opposition in trisyllabic tonal melodies ${ }^{14}$

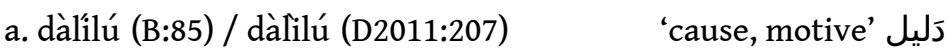


b. sàbàrá (D:861) / sàbárá (B:382)

c. fàtàwú (B:128) / fàtáwú (D2011:304)

d. kìbàrú (B:219) / kìbárú (D1987:92) 'shoe, sandal' صَبّاط

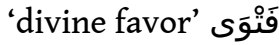

'news' خَبَر

\subsection{Exceptional LHH words}

ur discussion of tonal melodies in Arabic borrowings into Bambara thus far has focused on words for which we might expect a LHH melody but instead find a LLH melody. In our corpus of Arabic borrowings into Bambara, this accounts for all but three words. The remaining three words in (20) exhibit a LHH melody where we would otherwise expect a LLH melody. While the tonal melodies associated with these words do not follow neatly from the generalizations described above, other characteristics about them merit their being considered separately.

\section{(20) Exceptional LHH words}

\begin{tabular}{|c|c|c|c|c|}
\hline a. & biláyí & 'by God' & bi-llāhi & بِأَلَلهِ \\
\hline b. & màkámá & 'glory, renown' & maqāma & مَقامَة \\
\hline c. & kùránć & 'Quran' & qur'ān & 15 قُرْآن \\
\hline
\end{tabular}

To begin, (20a) is considered a single word in Bambara, yet it is derived from a phrasal construction in Arabic composed to two morphemes. The first syllable comes from the Arabic preposition ب 'with, by.' While we have indicated that elsewhere in Bambara the presence of prefixal material results in minor tonal melodies, it is yet unclear if the same principle can be applied here. Example (20b) is also puzzling; in the two dictionaries from which we have drawn our corpus, and others that we have since consulted, this word is spelled in a variety of ways and associated with several different tonal melodies. We have found it written as màkáámà,màkáámă,màkánmá, but also màkábáandmàkánbá

, which may call into question its etymology. Finally, (20c) has an exceptional melody which may be due to the presence of a glottal stop at the beginning of the first syllable; it is also a highly frequently occurring word.

It is certainly possible, as suggested by a reviewer, that the tonal patterns for these words, despite behaving different from others, may have resulted from a correlation between input stress and $\mathrm{H}$ tone in Bambara. The issue that arises as a result of such an analysis, however, is that it fails to explain why in numerous instances discussed above, as in words in (14) and (15), that there fails to be a similar correlation between $\mathrm{H}$ tone and stress. That is, this proposition implies that Bambara chose for these few borrowings to equate $\mathrm{H}$ tone and stress but then in so many more instances it failed to implement this correlation. While there is certainly more work that can be done to explore this point, we believe that the comparatively unusual properties of these three words likely contributed to their exceptionality in the overall borrowing schema.

In the next section, we discuss the characteristics of the Arabic loanword incorporation process as they relate to a recently proposed taxonomy of loanword prosody. We also briefly compare our analysis to that offered in Dumestre (1987) and then consider the 
properties of Arabic loanwords in Soninke and Soninke's potential role as an intermediary language between Arabic and Bambara.

\section{Discussion and concluding thoughts}

Scholarship on suprasegmental loanword phonology, as summarized in Kang (2010), indicates that languages with different types of prosodic systems (tone vs. pitch accent vs. stress) tend to behave in different ways when incorporating words from languages whose prominences are incompatible with their own. The data above illustrate that while Arabic loanword incorporation tends to approximate the mechanisms of typical Bambara tonal melody assignment in a number of ways, the process deviates from native mechanisms in some instances.

It should be clear that in loanword incorporation Bambara's tonal system does not behave like those of East Asian tone languages, the properties of which are summarized in Kang (2010). East Asian tone languages, by and large, ignore input prominences in favor of native prosodic patterns. Bambara instead behaves more closely, but not identically, to so-called 'stress' languages in that it places restrictions on the location of prominences and levels incompatible sequences in the process of loanword incorporation. Although Bambara does not faithfully preserve input prominence wholesale from Arabic, it has in some way permitted the retention of the input prominence in tonal melody assignment.

The tonal melodies associated with Arabic borrowings into Bambara have received little detailed attention in the literature besides their mention alongside other properties of the language's tonal system in Dumestre (1987). This may be because they are exceptional only relative to the tonal melodies found in Bambara words of non-Arabic origin. LLH and LHH tonal sequences are not unique to loanwords, yet their distribution in loanwords renders them unique. This very fact could also be part of the reason that the exceptional patterns have managed to persist in the phonologies of some speakers. As noted above, however, there are conflicting accounts regarding the synchronic tonal melodies that some loanwords exhibit. This suggests to us that the patterns are unstable and that this instability may portend their ultimate resolution in favor of the unmarked pattern in future generations of Bambara speakers. The total population of four million first language speakers of Bambara is dwarfed by an estimated ten million second language speakers (Lewis et al. 2014), which may also be a factor contributing to markedness leveling.

69 In the remainder of this section, we first discuss data on Bambara borrowings from Arabic in light of a recent taxonomy for loanword prosody proposed in Davis, et al. (2012). We then turn our attention to a comparison between our analysis and that offered earlier by Dumestre, as well as the potential role of Soninke as an intermediary language in the incorporation of Arabic words from the realms of trade and commerce. Finally, we explore the implications that these findings have for advancing our understanding of Bambara prosodic structure.

\subsection{Taxonomy of loanword prosody}

70 Many of the same principles of loanword incorporation that we discussed above are important factors in the preliminary taxonomy of loanword prosody outlined in Davis 
et al. (2012). This taxonomy builds on principles laid out in Kang (2010) by offering three somewhat loosely defined binary characteristics that a language might adopt in its overall loanword incorporation mechanism. These characteristics, as defined by Davis et al. (2012), are in (21), with shorthand terms adopted from the authors.

(21) Characteristics of loanword prosodic adaptation (Davis et al. 2012)

i. Do features of the source language figure into the assignment of prosody in the receiving language? [+/- source language];

ii. Is prosody assignment driven by rules or constraints specific to loanwords? [+/- specific to loanwords];

iii. Do segmental or suprasegmental features (including syllable type) play a role in adaptation? [+/- prosody]

By evaluating languages for these three characteristics, the authors provide a foundation for a taxonomic categorization of loanword prosody. In its current instantiation, the model identifies eight potential taxa. In their paper, Davis et al. consider seven languages that fit into five of the proposed taxonomic categories. We illustrate an adapted schematic of this taxonomy in (22). In order to evaluate the place of Bambara in this taxonomy, we consider each of these characteristics in turn as they relate to the loanword incorporation process discussed thus far.

(22) Taxonomy of loanword prosody (adapted from Davis et al. 2012)

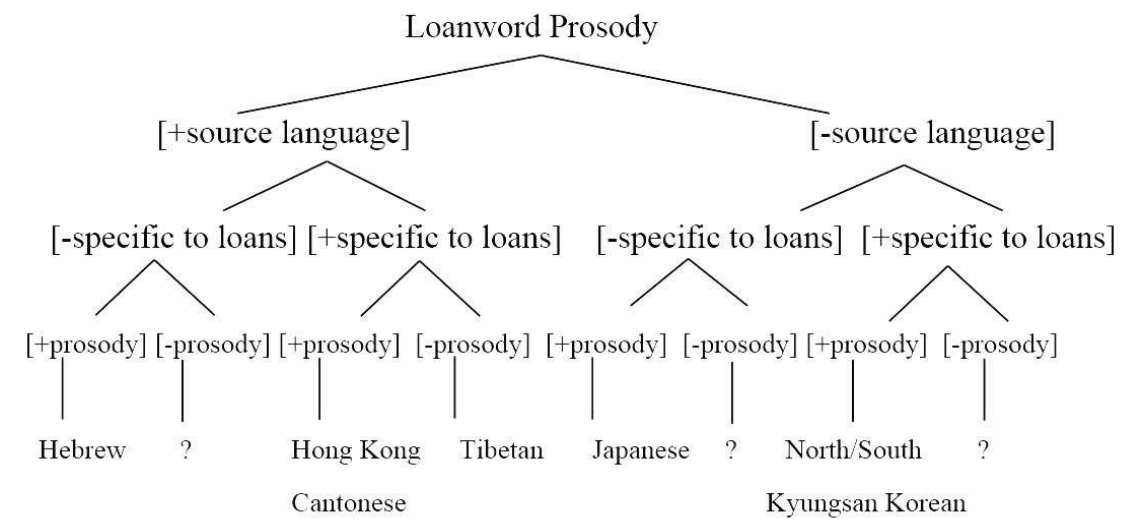

To begin, in the case of Arabic loanword incorporation into Bambara, we have seen that the prominent syllable in certain source words comes to be located in the second syllable of a trisyllabic Bambara borrowing. This second syllable prominence is incompatible with Bambara's prosodic structure and must be adapted in the loanword incorporation process. What we have illustrated is that in most instances, the second syllable in trisyllabic borrowings, despite having a 'strong' onset that would normally be associated with a $\mathrm{H}$ tone in Bambara words of non-Arabic origin, instead is associated with $\mathrm{L}$ tone. We have suggested that one reason for this stems from the fact that the Bambara L tone is marked (it is restricted in its distribution to prominent word-initial and foot-initial positions in the Bambara lexicon) and that the language preserved the location of the source word stress to the extent possible through this exceptional tonal profile. Because the loanword incorporation process is sensitive to 
and subsequently realizes input prosodic prominence, we propose that Bambara is [+source language] in the loanword prosody taxonomy.

Next, we illustrated that the tonal melodies assigned to loanwords, even in exceptional cases, are not unique to loanwords themselves. That is, both LHH and LLH melodies are found in native Bambara words, as well as in Arabic loans. Furthermore, we showed in (18) that in many instances, the tonal melody assignment process identically matches the typical mechanism found elsewhere in the Bambara lexicon. Because the melodies and mechanism are not unique to loanwords, we assign the value [-specific to loanwords] to Bambara.

We find further support for this particular characteristic in a small subset of loanwords encountered in our corpus which deviate from the HHH, LHH, and LLH melodies discussed above. The Arabic loanwords in (23) each exhibit a surface HLH tonal melody upon incorporation into Bambara. While these loans might seem to challenge our claims about the loanword incorporation mechanism, a closer look at Bambara phonology confirms that they do not deviate from our analysis.

(23) HLH tonal melody Arabic borrowings

\begin{tabular}{|c|c|c|c|c|}
\hline & Bambara & Gloss & & \\
\hline a. & kámàró & gum Arabic & thamār & تَمَار \\
\hline b. & mísèlí & needle & misalla & مِسَلَّة \\
\hline c. & ntámàró & palm date & tamr & تَمْر \\
\hline d. & tábàlé & drum & țabla & طَبْلَة \\
\hline
\end{tabular}

We mentioned in Section 5.2 that Bambara itself has a small set of 'minor' tonal melody words, some of which are derived via the prefixation of lá- and mă-, and whose tonal patterns deviate from the typical distribution of $\mathrm{H}$ vs. $\mathrm{LH}$. Some of those containing the lá- prefix have a HLH tonal melody. In (24), we provide a few examples of such words. The stems of these words are assigned a LH melody, and when they are preceded by the lá- causative marker, a HLH melody is the result. Although such words deviate somewhat from the typical Bambara tonal schema, they nonetheless exhibit an acceptable tonal pattern found in native words. Thus, the assignment of [-specific to loanwords] holds. ${ }^{16}$ We also thank V.Vydrine (personal communication) for pointing out that there are some high frequency words in Bambara not involving prefixation that exhibit a HLH melody, such as Bámàná'Bambara.'

(24) HLH tonal melody native Bambara words

\begin{tabular}{|l|l|l|l|l|}
\hline & Bambara & Gloss & \multicolumn{1}{|l|}{} \\
\hline a. & ládègé & 'to imitate' & & \\
\hline b. & lánùgú & 'to make grow' & & \\
\hline
\end{tabular}


\begin{tabular}{|l|l|l|l|l|}
\hline c. & látigé & 'to make pass' & & \\
\hline
\end{tabular}

76 of this characteristic provided by Davis et al. (2012) and summarized in (21). On the one hand, our data suggest that it is primarily prosody that drives the tonal melodies associated with Arabic loanwords in Bambara. We have seen that although Bambara restricts the location of metrical (durational) prominences in all positions, those that stem from illicit iambic sequences appear to be maintained to some degree in exceptional tonal melody assignment. While prosody plays this primary role in this process, we cannot overlook the tonal melody of words like those in (17), where segmental effects also appear to play a secondary role in the tonal outcome.

the topic of loanword prosody taxonomy further. Our attempt to define [+/-prosody] the topic of loanword prosody taxonomy further. Our attempt to define [+/- prosody] for Arabic to Bambara brings to light the possibility that this definition is not quite cut and dry in all instances. It might be necessary in a subsequent version of this taxonomy to introduce a third option at the lowest level, such that [+/- segmental] is also a valid choice alongside [+/-prosody]. The addition of this characteristic would therefore open the possibility to a three-way taxonomic difference at each terminus: [+prosody/ +segmental], [+prosody/-segmental], and [- prosody/+segmental]. We assume that [prosody/-segmental] is not a valid option. Investigating and validating the viability of these possibilities cross-linguistically is certainly beyond the scope of the current paper; however, at this point, we can assert that both prosodic and segmental structures play a role, albeit a non-equivalent one, in Arabic loanword incorporation into Bambara. Thus, we might assign Bambara [+prosody/+segmental].

\subsection{Comparison to Dumestre (1987)}

78

In Section 2, we introduced the central tenets of Dumestre's (1987: 85-93) analysis of the distribution of LHH vs. LLH tonal melodies in trisyllabic words. Dumestre based his analysis on many of the same principles that we discussed above but differed from the approach that we adopt in conflating all Bambara words into a single category. That is, Dumestre treated all Bambara words, regardless of their origin (e.g., French, Arabic, among others), as one category. As a result of this treatment, Dumestre needed to define two rules to account for the distribution of these melodies, the second of which was subject to caveats based on a somewhat artificial division of consonants into four strength categories (see (5)). Even then, however, there were exceptions to the rules that Dumestre hypothesized may be due to other factors. We have proposed in this paper that by adopting an approach which treats borrowed words separately from those that have not been borrowed into the language, we arrive at a principled explanation for the distribution of these melodies with fewer caveats and exceptions. We have illustrated that in the vast majority of instances, borrowed words whose input structures do not deviate significantly from those permitted in Bambara require no unusual adaptations, and their associated tonal melodies follow a native-like distribution. In most instances, words with unexpected melodies arise only in those instances where some adaptation must be made due to incongruities in the types and location of allowed prosodic prominences between the two languages. In this section, we revisit the trisyllabic words upon which Dumestre based his analysis. For the sake of 
space, we set aside all-H tone words whose melody arises uncontroversially in both analyses. Instead, we concentrate on those words with LHH vs. LLH melodies.

The LLH melody words i (25) are drawn from Dumestre (1987). This list contains both borrowed words and words that are not of foreign origin. In every instance, the words in this list follow an expected distribution of the LLH melody according to Leben's and Green's version of the 'weak' condition. Recall that there are two versions of the 'weak' condition: i) when a sonorant or glide occupies the onset of the second syllable of a foot; and ii) when a velar obstruent occupies the onset of the second syllable of a foot and is flanked by identical vowels.

(25) LLH words from Dumestre (1987)

\begin{tabular}{|c|c|c|c|c|c|}
\hline & Bambara & Gloss & & & \\
\hline a. & àràjó & radio & b. & bàràjí & benediction \\
\hline c. & bàrìgón & barrel & d. & bìrìntí & to beat \\
\hline e. & bòrògé & sterile & f. & bùgùrí & dust \\
\hline g. & bùlùkú & to plow & h. & bùnàkí & to remove skin \\
\hline i. & bùyàkí & guava & j. & dòlòkí & shirt \\
\hline $\mathrm{k}$. & fòròntó & pepper & 1. & hàlàlá & legal \\
\hline m. & jàgàró & bitter tomato & n. & jàhàdí & catastrophe \\
\hline o. & jàlákí & error & p. & jàmàná & country \\
\hline q. & jìgìné & granary & r. & kàmàrí & to conjoin \\
\hline s. & kغ̀mع̀sú & scissors & $\mathrm{t}$. & kòmòsí & to babysit \\
\hline u. & kònòntón & nine & v. & làgàré & last born \\
\hline w. & lògòbé & to grope & $\mathrm{x}$. & màgàsán & store \\
\hline$y$. & mìnìsé & bench & $\mathrm{z}$. & mònònkó & serval \\
\hline aa. & nàgàló & palate & bb. & nàmàsá & banana \\
\hline cc. & nànàyé & mint & dd. & nkàràngá & body louse \\
\hline ee. & nkòròngó & spitting snake & ff. & nàgàsá & grime \\
\hline gg. & pàyàsí & mattress & hh. & pùrùtí & to tear \\
\hline ii. & sàmìyé & rainy season & jj. & sòmònó & Somono \\
\hline kk. & sùgùrí & post fasting meal & 11. & tàmàkí & to hesitate \\
\hline
\end{tabular}




\begin{tabular}{|l|l|l|l|l|l|l|}
\hline mm. & wàgàndé & trunk & nn. & wàgàsí & to itch & \\
\hline oo. & wàyìbá & to humiliate & pp. & wòlòkó & to cool & \\
\hline qq. & yàmàrí & to authorize & rr. & yègèntú & to have hiccups & \\
\hline ss. & yògòrón & to menace & & & & \\
\hline
\end{tabular}

Likewise, (26) shows additional words (both borrowed and not) found in Dumestre (1987) that follow an expected, native-like distribution of the LHH melody according to Leben's and Green's version of the 'strong' condition. Recall that the 'strong' condition is when an obstruent occupies the onset of the second syllable of a trisyllabic word.

(26) LHH words from Dumestre (1987)

\begin{tabular}{|l|l|l|l|l|l|l|}
\hline & Bambara & Gloss & & & \multicolumn{2}{|l|}{} \\
\hline a. & àtáyí & tea & b. & bànbálí & seat & \\
\hline c. & bàndígí & pin & d. & bànfúlá & hat & \\
\hline e. & bùtígí & boutique & f. & fitíné & oil lamp & \\
\hline g. & fitírí & dusk & h. & fùnténí & heat & \\
\hline i. & gèngérén & stocky & j. & gèjúmá & Friday & \\
\hline k. & kàngárí & warning & l. & kònkóró & hunter's hat & \\
\hline m. & kòngólí & type of cross & n. & kòpóró & penny & \\
\hline o. & jàkúmá & cat & p. & jànkáró & sickness & \\
\hline q. & lòbááné & amber & r. & mànkútú & to praise & \\
\hline s. & nàngínć & fabric & t. & nòngírí & to genuflect & \\
\hline u. & sàfúné & soap & v. & sàngérén & kola worm & \\
\hline w. & sèngérén & dough & x. & tàkísí & taxi & \\
\hline y. & yàtí́mé & orphan & & & & \\
\hline
\end{tabular}

In addition, Dumestre (1987) includes the thirteen words in (27) which deviate from the expected distribution of LLH vs. LHH tonal melodies, as predicted in Leben's and Green's definitions of the 'weak' vs. 'strong' conditions seen in (25) and (26), respectively. We shall illustrate below that in all instances except perhaps for one, we can straightforwardly explain why these exceptions have arisen. 
(27) Additional words from Dumestre (1987)

\begin{tabular}{|l|l|l|l|l|l|l|}
\hline & Bambara & Gloss & & & & \\
\hline a. & fùgàrí & good-for-nothing & b. & jòkàjó & anemia & \\
\hline c. & kàfàrí & to atone & d. & kànémé & cross cousin & \\
\hline e. & kàsàbí & total & f. & làbìtó & colonial soldier & \\
\hline g. & làsàsí & hunting rifle & h. & sàbàtí & to be calm & \\
\hline i. & tàbàlí & table & j. & tòpòtó & to take good care & \\
\hline k. & tùsùnyé & male cook & l. & wèlúrú & velour & \\
\hline m. & wòkóló & spirit & & & & \\
\hline
\end{tabular}

To begin, (27a) is a borrowed word from the Arabic faqīr يُنَف 'indigent ' which behaves like the other Arabic borrowings in (14). Likewise, (27c) and (27h) are borrowed words from Arabic which we have already mentioned and accounted for in (12h) and (14i). Note that we did not include the former as an exceptional form, because inDumestre (2011) the word iskàfárí which has a non-exceptional tonal pattern. There is a discrepancy here between Dumestre (1987) and (2011), and we assume that the later reference is correct or perhaps that there is variation at play. Example (27e) is also a borrowing from Arabic and is accounted for in (17f). Thus, four of these thirteen exceptional words are Arabic borrowings (27a, c, e, h).

Seven additional words (27b, f, g, i, j, k, and l) are also borrowings. Four of these words have been borrowed into Bambara from French. (27f) làbìtó is presumably from the French laptot which is itself borrowed from Wolof. (27g) làsàsí is from the French noun phrase la chasse 'the hunt.' (27i) tàbàlí is from the French table 'table,' while (27k) tù sùnyć is said to be borrowed from the French cuisinier. Finally, (27l) wèlúrú is borrowed from the French velour. Like Arabic, French is a language whose pattern of stress does not align with that of Bambara. According to Scullen (1997), French words are comprised of iambic feet constructed from the right edge of a word. While it is not our intent to enter into a full consideration of the role of French prosodic structure on French borrowings into Bambara, the fact that the two languages have incongruous prosodic systems suggests that the exceptional tonal melodies associated with the borrowed French words in (27) may have arisen from similar principles to those discussed above for Arabic. (27b) jòkàjó is a loanword derived from the Baule [iso:bci] word jokuojo which refers to an ailment with symptoms similar to yellow fever (Roger 1993). We thank a reviewer for pointing out that (27j) tòpòtó 'to take good care' is borrowed from Wolof.

The remaining two words ( $27 \mathrm{~d}$ and $\mathrm{m}$ ) do not appear to be loanwords. Example (27d) is a Bambara word, but it reveals a discrepancy between two sources; in Dumestre (1987)

kànémé, while in Dumestre (2011) it is kànèmé. Assuming that the latter source is 
correct, this word is not problematic. For (27m) wòkóló, the sources that we have consulted indicate that this word has several variants which include wòkúló,wòfúló , andwòkló.

At least two of these variants would fail to meet the 'weak' condition needed for $\mathrm{L}$ tone spreading, so it is not surprising that this anomaly exists.

Thus, we have illustrate that all words provided in Dumestre (1987) either i) follow an expected pattern of tonal melody distribution; ii) are borrowed words from Arabic, French, Wolof, or Baule with incongruent input metrical structure that renders them unsurprisingly different from the patterns observed elsewhere; or iii) have reported variants that help to explain their tonal patterns. By appealing to a difference between native and borrowed words and predictable differences between them in terms of their metrical structure, we have arrived at a principled explanation for the distribution of the LLH and LHH tonal melodies with minimal caveats and exceptions.

\subsection{Thoughts on Soninke}

We have operated under the assumption in this paper that Classical Arabic is the source from which a majority of borrowed Arabic words entered Bambara. This follows from arguments articulated in works by Zappa $(2009,2011)$ and the fact that many borrowings stem from the areas of religion and religious law. We have, however, taken heed from the perspective given by Dumestre (1983) that some borrowings related to commerce and trade may have come through an intermediary language, and most likely via Soninke [iso:snk]. Soninke is a fairly close cousin of Bambara with which it shares a good deal of vocabulary; the geographic areas within which these two languages have primarily been spoken share a boundary. The main point that Dumestre (1983) emphasizes concerning Soninke as an intermediary language for Arabic borrowings is that those loans that arrived in Bambara via Soninke may prove to be more phonologically divergent than those borrowed directly from Arabic. While we believe that the analysis of the tonal melodies on Arabic loanwords into Bambara argued for above provides a cohesive viewpoint and concrete generalizations about the process with few deviations, in the remainder of this section, we aim to illustrate that from a metrical and tonal standpoint Soninke does not appear to have affected the borrowing process in a significant way.

To begin, it is important to note that the literature on Soninke tonology is smaller and less complete compared to what is available on Bambara tone. Until very recently, the most comprehensive resources available have been based on two dissertations (O. Diagana 1984 and Y. Diagana 1990) that unfortunately adopt divergent stances and come to rather different conclusions about the language's phonology and tonal system. Important to our interests here is that the basic facts of Soninke tonal melodies (i.e., what they are, how many there are, and how they are distributed) in these two works do not quite agree with one another. Beyond these works, there are several articles that discuss only particular aspects of Soninke phonology and tone (e.g., Creissels 1991, 1992; Y. Diagana 1985, 1990; Platiel 1981; Rialland 1990, 1991); Vydrine (2002) makes only a few passing remarks about the language. Creissels' (2016) reference grammar on the Kingi dialect of Soninke (published just a few months ago) is a thorough and much needed addition to the body of knowledge on the language. Concerning lexical resources, the only commercially available Soninke dictionary (O. Diagana 2011) that marks tone is unfortunately incomplete; this resource was posthumously published 
nearly a decade after the author's untimely death. Despite this fact, because the dictionary offers the largest number of words and therefore the widest variety of word shapes against which to view the distribution of tonal melodies, we have chosen to employ it as a baseline for the following discussion.

Concerning tonal melodies found in Soninke, it is immediately apparent that Soninke has a wider variety of possible melodies than Bambara. Setting aside for the moment the distribution of syllables containing long vowels and geminate consonants, the summary chart in (28) shows that Soninke words have three main 'low' melodies (LH, LLH, and LHL) and four main 'high' melodies (HH, HL, HHL, and HLH).

(28) Soninke tonal melodies

\begin{tabular}{|l|l|l|l|l|l|l|l|}
\hline & Melody & Soninke & Gloss & & Melody & Soninke & Gloss \\
\hline a. & LH & jàlá & fish fillet & f. & HL & kénè & odor \\
\hline b. & LLH & nùrùmé & perfume & g. & HHL & kátáyè & grease \\
\hline c. & LHL & nàmánì & to be warm & h. & HLH & sánàyé & detour \\
\hline e. & HH(H) & sáláxó & to be smooth & & & \\
\hline
\end{tabular}

Turning next the Soninke syllable inventory, it is again clear that distribution of complex syllable types in Soninke is more diverse than that of most varieties of Bambara. Soninke allows syllables containing long vowels (CV: ) and those closed by a single (CVC) or geminate consonant (CVC:);

in addition, these syllable types are found outside of word-initial contexts in monomorphemic words. Of these two syllable types, Bambara (at least historically) permits only CV

syllables, and these are restricted to word-initial position in monomorphemic words. While a footnote in Vydrine (2002) states that a 'heavy' vs. 'light' distinction between syllables does not play a role in Soninke, there is reason to explore this further. Platiel

(1981), for example, suggests that the distribution of tonal prominence in Soninke correlates with syllable type, and in our own survey of O. Diagana (2011), it appears that certain syllable type/tone sequences are either disallowed or relatively uncommon. For example, in trisyllabic words, words whose first syllable is short/light and second syllable is long/heavy (e.g., LH

:L and LL:

H) are far less common than those in which both the first and second syllable are long/

:H:L, L:L:H, and H:H:

heavy (e.g., L

L). There are also sequences that appear to be absent altogether, e.g., ${ }^{*} \mathrm{~L}: \mathrm{LH}$ and ${ }^{*} \mathrm{H}$ :

LL. While it is not our intent to provide an analysis of Soninke prosodic phonology, it appears at the very least that this remains an open area of inquiry. 
Finally, from the standpoint of segmental phonology, it is also clear that Soninke's consonant inventory shares more similarities with Arabic than does Bambara's. For example, both Soninke and Arabic have [q] and [

$\chi]$ in their native inventories, while these are absent from Bambara. ${ }^{17}$

Thus, concerning both the distribution of segments and syllable types, Soninke is less divergent from Arabic than Bambara is.

Important to our point here is the fact that equivalent Arabic borrowings in both Soninke and Bambara are, for all intents and purposes, independent of one another from a tonal perspective. The comparison of representative examples given in (29) illustrates that there is no clear correlation between $\mathrm{H}$ melody and $\mathrm{L}$ melody words in Bambara vs. Soninke. Some H melody Soninke words have a L melody in Bambara and vice versa. This suggests that from the standpoint of tonal melody specification in loanword incorporation, each of the two languages has employed its own strategy for lexical tonal melody assignment. Moreover, this comparison (however preliminary) suggests that Soninke does not appear to have exerted an overt tonal influence in the Bambara loanword incorporation process. There is, however, clearly much more to be said about Soninke prosody that must be left to future research.

(29) Comparison of Bambara and Soninke tonal melodies in Arabic borrowings

\begin{tabular}{|c|c|c|c|c|c|}
\hline & Bambara & & Soninke & & \\
\hline & Example & Melody & Example & Melody & Gloss \\
\hline a. & dáábá & $\mathrm{HH}$ & dáábà & HL & beast \\
\hline b. & dárájá & HHH & dárájà & HHL & influence \\
\hline c. & sábálí & HHH & sàbárì & LHL & patience \\
\hline d. & síbírí & $\mathrm{HHH}$ & síbítì & HHL & Saturday \\
\hline e. & fájírí & $\mathrm{HHH}$ & fájìrí & HLH & dawn \\
\hline e. & sìlàmé & LLH & sìláámù & LHL & Muslim \\
\hline f. & kàbàrú & LHH & kàbárì & LHL & to atone for \\
\hline g. & mìsírí & LHH & mìsíírì & LHL & mosque \\
\hline h. & jènz̀yá & LLH & jéénìyé & HLH & adultery \\
\hline i. & màrìfá & LLH & máráfà & HHL & rifle \\
\hline j. & kùtùbá & LLH & xútúbà & HHL & sermon \\
\hline
\end{tabular}




\section{Concluding thoughts}

91 Our observations concerning the mechanism and outcomes of Arabic loanword incorporation add to a growing body of research focused on defining properties of Bambara prosodic structure in particular (e.g., Bamba 1991; Green 2010, 2013, 2015; Leben 2002, 2003; Rialland \& Badjimé 1989; Weidman \& Rose 2006) and prosodic structure in other Mande languages (Green et al. 2013; Kuznetsova 2007; Le Saout 1979; Vydrine 2002, 2003, 2010). This paper supports the generally accepted observation that prosodic structure plays a role in Mande languages (Vydrine 2010), yet detailed research on the degree to which it bounds or otherwise constrains certain segmental or suprasegmental processes in a given language is nascent. It is beyond the scope of this paper to explore in detail the state of the science across all branches of Mande, so we limit ourselves here to some highlights of this work in relation to Bambara and insights that our current work on loanword incorporation might offer.

92 The role of the foot in Bambara phonology has been taken up in recent works from both tonal (Leben 2002, 2003; Rialland \& Badjime 1989; Weidman \& Rose 2006) and segmental (Green 2010; Green et al. 2012) perspectives. Concerning Bambara, these perspectives have been summarized most recently in Green (2015), who offers evidence that prosodic feet in Bambara are bimoraic, maximally disyllabic trochees that are parsed from left to right in all instances (although see Vydrine 2010 for an alternative viewpoint on Bambara foot structure). These claims are grounded in observations of segmental and tonal distribution as well as the outcomes of segmental and tonal processes that occur in several varieties of the language. One important point concerns several pieces of independent evidence illustrating that Bambara avoids the creation of iambic feet as the result of two complementary segmental deletion processes and instead favors phonological prominences (i.e. complex syllables) in left-edge, foot-initial positions and/or the creation of trochaic feet.

Our observations concerning Arabic loanword incorporation appear to be in line with these predictions, although there is certainly more work that can be done, particularly related to the discrepancies between tonal melodies in borrowed words found in various sources and the possibility of an ongoing resolution of exceptional tonal melody assignment in favor of patterns observed in words of non-foreign origin. We have proposed that Bambara's avoidance of iambic sequences is an important factor in the loanword incorporation process but that there are a number of other factors at play. Viewed alongside contemporary perspectives on loanword phonology and typological predictions about prosodic feet in the literature on prosodic and metrical phonology, our findings offer support to earlier proposals for trochaicity in Bambara foot structure.

What we have done in this paper is to shed light on a perennially overlooked subset of words that have been incorporated into Bambara from Arabic. These words exhibit tonal melodies that are identical to those found in Bambara words of non-Arabic origin, yet their distribution is sometimes unlike that found in elsewhere in the lexicon. We have argued that this exceptional tonal melody distribution appears to have resulted from the resolution of incompatible prosodic prominences between the lending and borrowing languages. We illustrated that a greater number of exceptional forms in Arabic loans are not encountered in Bambara because some Arabic inputs contain prominences that are more in-line with and therefore compatible with Bambara 
prosodic structure. We discussed characteristics of Bambara loanword incorporation in light of typological predictions made in Kang (2010) and suggested a potential modification to the taxonomy of loanword prosody offered in Davis et al (2012) that might better accommodate languages like Bambara in which both prosodic and segmental characteristics figure into the loanword incorporation mechanism. Finally, we discussed our findings in relation to ongoing research on Bambara. We suggest that the adaptations made in Arabic loanword incorporation implicate trochaic feet in Bambara.

One important outcome of the current paper in comparison to earlier viewpoints on tonal melody distribution in trisyllabic Bambara words is that our analysis does not rely on a series of rules. Rather, by considering the phonology of non-borrowed vs. borrowed words separately, we can arrive at a principled generalization for the tonal melody distribution that we and others have observed. That is, in Bambara words not of Arabic origin and in borrowings that contain no incompatible input prominences, the expected distribution of LLH and LHH tonal melodies obtains. Exceptional patterns arise only in loanwords and only in those loanwords whose source correspondent contains a prominence that cannot be accommodated by Bambara's phonology. Thus, our analysis better predicts why most Arabic words do not behave exceptionally as well as why the marked distribution of the LH tonal melody appears unstable and is on a trajectory to be resolved in the direction of patterns found elsewhere in Bambara. DIAGANA Ousmane Moussa, 1984, Le parler Sónîké de Kaedi (Mauritanie) : syntaxe et sens, Thèse d'État, Paris, Université Paris V.

\title{
BIBLIOGRAPHY
}

\author{
AL-ANI Salman, 1992, "Stress variation of the construct phrase in Arabic: A spectrographic \\ analysis", Anthropological Linguistics, no 34, pp. 248-276.

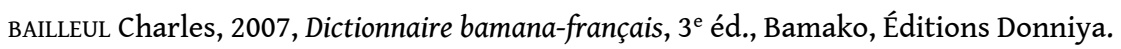 \\ BAILLEUL Charles, ARTEM Davydov, ERMAN Anna, MASLINSKY Kirill, MÉRIC Jean Jacques,VYDRINE \\ Valentin, 2011-2014,Bamadaba : Dictionnaire \\ électronique bambara-français, avec un index français-bambara.URL : \\ http://cormand.huma-num.fr/bamadaba.html. \\ BAMBA Moussa, 1991, De l'interaction entre tons et accent, $\mathrm{PhD}$ dissertation, Université du Québec à \\ Montréal. \\ BENNETT Ryan, 2012, Foot-conditioned phonotactics and prosodic constituency, PhD dissertation, \\ University of California, Santa Cruz. \\ BIRD Charles S., 1966, “Determination in Bambara”, Journal of West African Languages 3(1), pp. 5-11.
}


COURTENAY Karen, 1974, "On the nature of the Bambara tone system", Studies in African Linguistics 5(3), pp. 303-323.

CoWAN J. Milton (ed.), 1994, The Hans Wehr Dictionary of Modern Written Arabic (4th ed.), Urbana, IL, Spoken Language Services.

CREISSELS Denis, 1978, «À propos de la tonologie du bambara : réalisations tonales, système tonal et la modalité nominal 'défini' ", Afrique et langage, $\mathrm{n}^{\circ}$ 9, p. 5-70.

CREISSELS Denis, 1988, Études Manding $n^{\circ} 1$ - Le système tonal du bambara standard, Grenoble, Centre de linguistique africaine de l'Université des langues et lettres de Grenoble.

CREISSELS Denis, 1991, «Remarques sur le système tonal du soninké », Linguistique Africaine, nº 6, p. 129-134.

CREISSELS Denis, 1992a, « Tonologie du bambara : bilan et perspectives », Mandenkan, $\mathrm{n}^{\circ}$ 24, p. 1-45.

CREISSELS Denis, 1992b, «Quelques précisions sur la tonalité du verbe soninké », Linguistique Africaine, $\mathrm{n}^{\circ}$ 8, p. 79-90.

CREISSELS Denis, 2009, Le Malinké de Kita : un parler mandingue de l'ouest du Mali, Köln, Rüdiger Köppe. CREISSELS Denis, 2016, « Phonologie segmentale et tonale du soninké (parler du Kingi) », Mandenkan, $n^{\circ}$ 55, p. 3-174.

CREISSELS Denis, GRÉGOIRE Claire, 1993, « La notion de ton marqué dans l'analyse d'une opposition tonale binaire : le cas du mandingue », Journal of African Languages and Linguistics, no 14, pp. 107-154.

DAVIS Stuart, NATSUKO Tsujimura, JUNG-YUEH Tu, 2012, "Toward a Taxonomy of Loanword Prosody", Catalan Journal of Linguistics, no 11, pp. 13-39.

DE JONG Kenneth, ZAWAYDEH Bushra Adnan, 1999, "Stress, duration, and intonation in Arabic wordlevel prosody", Journal of Phonetics, no 27, pp. 3-22.

DELAFOSSE Maurice, 1929-1955, La langue mandingue et ses dialectes (Malinké, Bambara, Dioula). Tome 1: Introduction, grammaire, lexique français-mandingue, Paris, Librairie Orientaliste Paul Geuthner. DIAGANA Ousmane Moussa, 2011, Dictionnaire soninké-français (Mauritanie), Paris, Karthala. DIAGANA Yacouba, 1985, «Éléments de phonologie du soninké », Mandenkan, n 10, p. 75-87. DIAGANA Yacouba, 1990, «La tonalité du constituant nominal en soninké », Mandenkan, $\mathrm{n}^{\circ}$ 19, p. 13-37.

DIAGANA Yacouba, 1990, Éléments de grammaire du soninké, Thèse de doctorat, Paris, Inalco. DIARRA Boubacar, 1976, Étude acoustique et fonctionnelle des tons du bambara, Thèse de doctorat, Aix-en-Provence, Université de Provence, Institut de phonétique.

DUMESTRE Gérard, 1983, « Note à propos des termes bambara empruntés à l'arabe ", in Langue arabe et langues africaines : mémoire spécial du Centre d'études sur les relations entre le monde arabe et l'Afrique et du Centre d'études sur l'Océan indien occidental, Paris, Conseil international de la langue française, p. 13-20.

DUMESTRE Gérard, 1987, Le bambara du Mali : essais de description linguistique, Thèse d'État, Université Sorbonne Nouvelle-Paris 3/Institut des langues orientales.

DUMESTRE Gérard, 2003, Grammaire fondamentale du bambara, Paris, Karthala.

DUMESTRE Gérard, 2011, Dictionnaire bambara-français, Paris, Karthala. 
DWYER David, 1976, “The analysis of Bambara polarization”, Studies in African Linguistics Supplement 6, pp. 27-38.

GREEN Christopher R., 2010, Prosodic phonology in Bamana (Bambara): Syllable complexity, metrical structure, and tone, $\mathrm{PhD}$ dissertation, Indiana University.

GREEN Christopher R., 2013, "Formalizing the prosodic word domain in Bambara tonology", Journal of West African Languages, no 50, pp. 61-84.

GREEN Christopher R., 2015, “The foot domain in Bambara”, Language 91(1), pp. e1-e26.

GREEN Christopher R., ANDERSON Jonathan C., OBENG Samuel G., 2013, "Interacting tonal processes in Susu", Mandenkan, no 50, pp. 61-84.

GREEN Christopher R., DAVIS Stuart, DIAKITE Boubacar, BAERTSCH Karen, 2014, “On the role of margin phonotactics in Colloquial Bamana complex syllables", Natural Language \& Linguistic Theory, no 32(2), pp. 499-536.

HAYES Bruce, 1985, "Iambic and Trochaic Rhythm in Stress Rules”, Berkeley Linguistics Society, no 11 , pp. 429-446.

HAYES Bruce, 1989, “The Prosodic Hierarchy in meter", in KIPARSKY Paul, yOUMANS Gilbert (eds.), Rhythm and Meter, Orlando, Academic Press, pp. 201-260.

HYMAN Larry M., 1978, “Historical tonology”, in FROMKIN Victoria A. (eds.), Tone: A Linguistic Survey, New York, Academic Press, pp. 257-269.

HYMAN Larry M., 2007, “Universals of tone rule: 30 years later”, in RIAD Tomas, GUSSENHOVEN Carlos (eds.), Tones and Tunes: Studies in Word and Sentence Prosody, Berlin-New York, Mouton de Gruyter, pp. 1-34.

HYMAN Larry M., RUSSELL G. Schuh, 1974, "Universals of tone rules: Evidence from West Africa”, Linguistic Inquiry 5(1), pp. 81-115.

ITO Junko, MESTER Armin, 2013, “Prosodic subcategories in Japanese”, Lingua, no 124, pp. 20-40.

KANG Yoonjung, 2010, “Tutorial overview: Suprasegmental adaptation in loanwords”, Lingua, no 120 , pp. 2295-2310.

KENSTOWICZ Michael, 2007, "Salience and similarity in loanword adaptation: A case study from Fijian", Language Sciences, no 29, pp. 316-340.

KUZNETSOVA Natalia, 2007, « Le statut fonctionnel du pied phonologique en Gouro », Mandenkan, $\mathrm{n}^{\circ} 43$, pp. 13-45.

LANE Edward William, 1863, An Arabic-English lexicon, London, Willams and Norgate.

LEBEN William R., 2002, “Tonal feet”, in GUT Ulrike, GIBBON Dafydd (eds.), Proceedings, Typology of African Prosodic Systems, University of Bielefeld, Bielefield Occasional Papers in Typology, pp. 27-40.

LEBEN William R., 2003, “Tonal feet as tonal domains”, in MUGANE John (ed.), Trends in African Linguistics 5: Linguistic typology and representation of African languages, Trenton (NJ), Africa World Press, pp. 129-138.

LEWIS M. Paul, SIMONS Gary F., FENNIG Charles D. (eds.), 2014, Ethnologue: Languages of the World (17 $7^{\text {th }}$ ed.), Dallas (TX), SIL International. URL :http://www.ethnologue.com (accessed 17 February 2015). 
MARTÍNEZ-PARICIO Violeta, 2013, An exploration of minimal and maximal metrical feet, $\mathrm{PhD}$ dissertation, University of Tromsø.

MCCARTHY John J., PRINCE Alan S., 1990, "Foot and word in prosodic morphology: The Arabic broken plural", Natural Language \& Linguistic Theory, no 8, pp. 209-283.

NESPOR Marina, VOGEL Irene, 1986, Prosodic phonology, Dordrecht, Foris.

Platiel Suzy, 1981, «Phonologie du soninké : une tentative d'analyse dynamique », Mandenkan, $\mathrm{n}^{\circ} 1$, pp. 79-107.

PRINCE Alan, 1991, "Quantitative consequences of rhythmic organization”, Chicago Linguistics Society, no 26(2), pp. 355-398.

RIALLAND Annie, BADJIMÉ Mamadou, 1989, «Réanalyse des tons du Bambara: des tons du nom à l'organisation générale du système ", Studies in African Linguistics, no 20, p. 1-28.

RIALLANDAnnie, 1990, « La structure du système tonal soninké », Linguistique Africaine, nº 5, pp . 49-76.

RIALLAND

Annie, 1991, «À propos de la prosodie du soninké : réponse à Denis Creissels et réflexions sur la valeur explicative des analyses »,

Linguistique Africainen $^{\circ}$ 7, pp. 117-124.

RIALLAND Annie, BADJIMÉ Mamadou (Sangaré), 1989, « Réanalyse des tons du Bambara : des tons du nom à l'organisation générale du système », Studies in African Linguistics, no 20, p. 1-28.

ROGER Myriam, 1993, «Sumaya dans la régionde Siakasso : Une entité en évolution », in BRUNET-JAILLYJoseph (éd.),Se soigner au Mali : une contribution des sciences sociales,

Paris, Karthala-ORSTOM, pp. 83-125.

SCULLEN Mary Ellen, 1997, French prosodic morphology: A unified account, Bloomington, Indiana University Linguistics Club Publications.

SELKIRK Elisabeth, 1978, "On prosodic structure and its relation to syntactic structure", in FRETHEIM Thorstein (ed.), Nordic prosody II, Trondheim (Norway), TAPIR, pp. 111-140.

SELKIRK Elisabeth, 1984, Phonology and Syntax: The Relation between Sound and Structure, Cambridge, MIT Press.

SELKIRK Elisabeth, 1986, “On derived domains in sentence phonology”, Phonology Yearbook, no 3, pp. 371-405.

SELKIRK Elisabeth, 1996, "The prosodic structure of function words", in MORAN James L., DEMUTH Katherine (eds.), Signal to Syntax: Bootstrapping from Speech to Grammar in Early Acquisition, Mahwah (NJ), Lawrence Erlbaum, pp. 187-213.

SELKIRK Elisabeth, 2011, “The syntax-phonology interface”, in GOLDSMITH John, RIGGLE Jason, YU Alan (eds.), The Handbook of Phonological Theory, Malden, Wiley-Blackwell, pp. 435-484.

TAMARI Tal, 2006, « L'enseignement islamique traditionnel de niveau avancé : cursus, pédagogie, implications culturelles et perspectives comparatives ", Mande Studies, no 8, pp. 39-62.

VYDRINE Valentin, 2002, "Some hasty notes on the ways of the evolution of Mande tonal systems", in NICOLAÏ Robert, zIMA Petr (eds.), Lexical and structural diffusion, Université de Nice, Faculté des lettres, arts et sciences humaines, pp. 243-264. 
VYDRINE Valentin, 2003, «La phonologie Gouro : deux décennies après Le Saout », Mandenkan, $\mathrm{n}^{\circ} 38$, p. 89-113.

VYDRINE Valentin, 2010, « Le pied métrique dans les langues mandé », in FLORICIC Franck (éd.), Essais de typologie et de linguistique générale : Mélanges offerts à Denis Creissels, Lyon, ENS Éditions, p. 53-62.

VYDRINE Valentin, 2014, "Tone and stress in Bambara: A lack of correlation as a theoretical challenge", in KOLPACHKOVA E. N. (ed.), Languages of the countries of the Far East, South-Eastern Asia, and Western Africa. Proceedings of the XI ${ }^{\text {th }}$ international conference (St. Petersburg), St. Petersburg, Studia NP-print [in Russian], pp. 32-38.

WATSON Janet C. E., 2001, "Word stress in Arabic", in VAN OOSTENDROP Marc, EWEN Colin J., HUME Elizabeth (eds.), The Blackwell Companion to Phonology: General issues and segmental phonology, Volume 5, Oxford, Wiley-Blackwell, pp. 2990-3018.

WATSON, Janet C. E., 2002, The Phonology and Morphology of Arabic, Oxford, Oxford University Press. WEIDMAN Scott, ROSE Sharon, 2006, “A foot-based reanalysis of edge-in tonal phenomena in Bambara", in BAUMER Donald, MONTERO David, sCANLON Michael (eds.), Proceedings of the $25^{\text {th }}$ West Coast Conference on Formal Linguistics, Somerville (MA), Cascadilla Proceedings Project, pp. 426-434. ZAPPA Francesco, 2009, «Écrire l'islam en bambara : lieux, réseaux et enjeux de l'entreprise d'al-Hâjj Modibo Diarra », Archives de Sciences Sociales des Religions, nº 147, p. 167-186.

ZAPPA Francesco, 2011, "When Arabic resonates in the words of an African language: Some morphological and semantic features of Arabic loanwords and calques in Bambara", in LANCIONI Giuliano, BETTINI Lidia (eds.), The Word in Arabic, Leiden, Brill, pp. 229-249.

\section{NOTES}

1. This generalization holds for the normative, 'standard' variety of the language, as described in well-cited sources such as Dumestre $(1987,2003)$.

2. Dumestre (1987: 92) also notes the unusual 'weak' behavior of Bambara velar consonants. Also, while nasal segments in Bambara $[\mathrm{m}, \mathrm{n}, \mathrm{n}, \mathrm{y}$ ] pattern with other sonorants in permitting L tone spreading (e.g.,bànànkú 'manioc'), the nasal+consonant clusters that emerge when a nasalized vowel precedes a consonant over a syllable boundary block tone spreading (e.g.,

dùngúrú'wooden plank').

3. A reviewer suggests an alternative analysis in which /LLH/ is the lexical melody for trisyllabic words; this would be in line with the dissimilationist perspective that we argued against above. In such an analysis, the [LLH] tonal melody that we observe in Arabic loanwords would arise because Bambara chooses the underlying melody when faced with a problematic phonological incompatibility. While this might appear to be a promising possibility, it would pose a problem of explaining a non-morphologically-triggered tonal dissimilation (/LLH/ $\rightarrow$ [LHH]) in many Bambara words of non-Arabic origin, which as we have discussed above is phonologically unnatural. The same reviewer, however, also suggests that the mechanism used in Bambara for tonal melody assignment in trisyllabic words could have arisen historically from the phonologization of a morphological rule (which we take to mean compacité tonale) owing to the fact that there are many trisyllabic words in the language that are not monomorphemic. This is also a possibility to bear in mind, but we are aware of no other evidence to suggest that Bambara necessarily treats trisyllabic words in this way. As such, we believe that further inquiry into this 
possibility must be left to future research. Another reviewer points out, and indeed we discuss later in Section 5.4, that it is sometimes the case that variation is encountered pertaining to the overall $\mathrm{H}$ vs. LH tonal melody associated with a Bambara trisyllabic word. That is, while for some speakers a word may exhibit an all-H melody, the same word for other speakers may exhibit one of the two L tonal melody allomorphs. This variation can be found even in a comparison of wellcited lexical resources like Dumestre (2011) and Bailleul (2007). Of key importance to our analysis is not the lexical assignment of $\mathrm{H}$ vs. $\mathrm{LH}$, but rather the distribution of tones across words of a particular shape.

4. We thank a reviewer for pointing out that the phonetic realization of the tonal melody assigned to a Bambara verb may be altered due to a variety of factors such as its location relative to another clausal constituent and intonation. While a verb may be the final element of a clause or sentence, it may also be followed for example by an adverb or postpositional phrase. The infinitival form of a verb may also be used as a nominal, and therefore can occur elsewhere in a clause or sentence. These and other factors may result in the surface tonal melody of a given verb differing from its lexical (phonological) representation. When we provide a Bambara verb in this paper, we present it in its infinitival form, and the tonal melody associated with it is its lexical melody.

5. While it is somewhat tangential to our main argument, we can illustrate that only a two-way distinction between 'weak' and 'strong' consonants is necessary in Bambara. The four degrees of strength defined by Dumestre have little predictive power in defining the outcomes of affaissement. Although it is true that fourth degree consonants (liquids) are most susceptible to affaissement, as are third degree consonants (nasals), it is also true that some second degree consonants (glides) and the first degree velar obstruents [k] and [g] accommodate $\mathrm{L}$ tone spread. Because this four-way distinction does not appear to be necessary for any particular component of Bambara phonology, we believe that a simpler solution is to define glides, liquids, nasals, and the velar obstruents as 'weak' consonants, while all others are 'strong.'

6. In addition, Leben $(2002,2003)$ suggests that foot headedness is lexically-specified for each word, but see Green (2015) for further discussion on this point.

7. As Green (2015) also points out, the gradual loss of long vowels in word-initial position in Bambara (except in monosyllabic words) offers further support to this proposal of trochaicity, as unbalanced trochees are in the process of removing their initial metrical prominence, thereby becoming more ideally balanced.

8. We have chosen durba 'boldness to engage in, or undertake, war, and any affair' based on Lane (1863: 867). The definition in Cowen (1994:319) 'habit, skill' is a less obvious connection. V. Vydrine (personal communication) suggests that jarraba بَنَ) 'to try, attempt' might be more appropriate, but this of course would result in a part of speech mismatch between the Arbic and Bambara.

9. This is a clear case of metathesis between the Arabic input and its Bambara counterpart.

10. We discuss later, though, that the presence of such heavy syllables is in flux in contemporary Bambara grammar.

11. V. Vydrine (personal communication) points out that this word likely passed through Soninke, where the equivalent is dùnyàrê.

12. The tone patterns associated with this word vary significantly across sources; variants that we have encountered include tàsàlén,tásálén, andtásàlén

. Another possibility is that this word is derived from Arabic wordșatl

'bucket,' and has undergone metathesis.

13. We assume for (18n) that while the input contains a final heavy syllable, this ends up being unproblematic, as it is balanced by a word-initial heavy syllable. (180) illustrates a monosyllable input lacking any complicating segmental prominences like those discussed in (17). 
14. Specific references pertain to (B) Bailleul (2007) and (D) Dumestre (1987) or (2011). Concerning (19e), we thank Valentin Vydrine for pointing out that D (2011:516) provides additional tonal variants, including kibàrú and kibárǔ.

15. V. Vydrine (personal communication) points out that Dumestre provides kùràne as another alternative. This form would support the viewpoint discussed earlier that exceptional melodies are being leveled in the direction of more common tonal melody patterns.

16. We argued against the possibility of alternative footing above for words with a LLH melody. We did this because no Bambara words prefixed by lá- or mă- exhibit a $(\mathrm{L})(\mathrm{LH})$ pattern. We have just illustrated in 0 , however, that there is a native precedent for the $(\mathrm{H})(\mathrm{LH})$ tonal pattern, so footed. While more inquiry into this matter is necessary, we believe that this is a reasonable proposal given other characteristics of Bambara phonology and the overall loanword incorporation process. Thus, this slightly different outcome still approximates input prominence; we can maintain the assignment of [+source language].

17. We thank a reviewer for pointing out that while these two sounds are contrastive segments in Arabic, they are allophones of a single phoneme in Soninke.

\section{ABSTRACTS}

There is a rich descriptive history on Bambara tonology in the published literature (e.g. Bird 1966; Courtenay 1974; Creissels 1978, 1988, 1992; Diarra 1976; Dumestre 1987; Dwyer 1976). Despite the existence of several seminal works on the subject, certain details of the language's tonal system remain unclear. Scholars have developed deep knowledge about the lexical and grammatical functions of Bambara tone, yet the dependency of tones and tonal processes on prosodic structure has only more recently been explored in detail (Green 2013, 2015; Leben 2002, 2003; Weidman and Rose 2006; Vydrine 2002, 2010). In this paper, we aim to contribute to this ongoing trend by considering a role played by prosodic structure in one particular set of Arabic borrowings for which the assignment of tonal melodies differs from that found in words of nonArabic origin. We explore possible explanations for this divergence that relate to contemporary scholarship on the properties of Bambara's prosodic structure. Our point of view on this subject differs from earlier analyses (e.g., Dumestre 1987) in that we propose that prosodic structure plays an important role in the assignment of Bambara tonal melodies. Finally, we relate our findings to a taxonomic model of loanword prosody in Davis et al. (2012) and consider the bearing that our findings may have on the typology of Bambara prosodic structure alongside other Mande languages.

Il existe une riche histoire descriptive sur la tonologie du bambara dans la littérature publiée (par exemple Bird 1966, Courtenay 1974, Creissels 1978, 1988, 1992, Diarra 1976, Dumestre 1987, Dwyer 1976). Malgré l'existence de plusieurs travaux séminaires sur ce sujet, certains détails du système tonal de la langue demeurent obscurs. Les chercheurs ont développé une connaissance approfondie des fonctions lexicales et grammaticales du ton en bambara, mais la dépendance des tonalités et des processus tonals sur la structure prosodique n'a été étudiée que plus récemment (Green 2013, 2015, Weiden et Rose, 2006; Vydrine 2002, 2010). Dans cet article, nous cherchons à contribuer à cette tendance en considérant le rôle joué par la structure prosodique dans un ensemble particulier d'emprunts arabes pour lesquels l'attribution de mélodies tonales diffère de celle trouvée dans des mots d'origine non arabe. Nous explorons les explications possibles de 
cette divergence qui se rapportent à l'érudition contemporaine sur les propriétés de la structure prosodique du bambara. Notre point de vue sur ce sujet diffère des analyses antérieures (par exemple, Dumestre 1987) en ce que nous proposons que la structure prosodique joue un rôle important dans l'attribution de mélodies tonales en bambara. Enfin, nous relions nos découvertes à un modèle taxonomique de prosodie d'emprunts dans Davis et al. (2012) et considérons la portée que nos résultats peuvent avoir sur la typologie de la structure prosodique du bambara aux côtés d'autres langues mandées.

ОПИСАНИЮ ТОНОЛОГИИ БАМАНА ПОСВЯЩЕНА БОГАТАЯ ЛИТЕРАТУРА (В ЧАСТНОСТИ,Bird 1966;

Courtenay 1974; Creissels 1978, 1988, 1992; Diarra 1976; Dumestre 1987; Dwyer 1976). ИМЕЮЩИЕСЯ ПУБЛИКАЦИИ ОСВЕЩАЮТ КЛЮЧЕВЫЕ ВОПРОСЫ В ЭТОЙ ОБЛАСТИ, ОДНАКО НЕКОТОРЫЕ ДЕТАЛИ БАМАНСКОЙ ТОНОЛОГИИ ВСЁ ЖЕ ОСТАЮТСЯ НЕЯСНЫМИ. ИССЛЕДОВАТЕЛИ УДЕЛИЛИ МНОГО ВНИМАНИЯ ЛЕКСИЧЕСКИМ И ГРАММАТИЧЕСКИМ ФУНКЦИЯМ БАМАНСКОГО ТОНА, ОДНАКО ЗАВИСИМОСТЬ ТОНОВ И ТОНАЛЬНЫХ ПРОЦЕССОВ ОТ ПРО СОДИЧЕСКОЙ СТРУКТУРЫ БЫЛА РАССМОТРЕНА В ДЕТАЛЯХ ЛИШЬ НЕДАВНО(Green 2013, 2015; Leben 2002, 2003; Weidman and Rose 2006; Vydrine 2002, 2010). ЭТА СТАТЬЯ ИМЕЕТ ЦЕЛЬЮ УКРЕПИТЬ ЭТО НАПРАВЛЕНИЕ, ПРОАНАЛИЗИРОВАВ РОЛЬ ПРОСОДИЧЕСКОЙ СТРУКТУРЫ НА КОНКРЕТНОЙ ВЫБОРКЕ, А ИМЕННО, НА АРАБСКИХ ЗАИМСТВОВАНИЯХ, ПРИПИСЫВАНИЕ КОТОРЫМ ТОНОВЫХ КОНТУРОВ ПОДЧИНЯЕТСЯ ОСОБЫМ ПРАВИЛАМ. РАССМАТРИВАЮТСЯ РАЗЛИЧНЫЕ ОБЪЯСНЕНИЯ ТАКИХ РАЗЛИЧИЙ, СВЯЗАННЫХ С СОВРЕМЕННЫМИ ВЗГЛЯДАМИ НА ОСОБЕННОСТИ ПРОСОДИЧЕСКОЙ СТРУКТУРЫ БАМАНА. НАША ТОЧКА ЗРЕНИЯ ПО ЭТОМУ ВОПРОСУ ОТЛИЧАЕТСЯ ОТ ПОЗИЦИЙ ПРЕДШЕСТВЕННИКОВ (СМ., В ЧАСТНОСТИ, Dumestre 1987), ПОСКОЛЬКУ МЫ СЧИТАЕМ, ЧТО В ЯЗЫКЕ БАМАНА ПРОСОДИЧЕСКАЯ СТРУКТУРА ИГРАЕТ ВАЖНУЮ РОЛЬ В ПРИПИСЫВАНИИ ТОНАЛЬНЫХ КОНТУРОВ. НАКОНЕЦ, МЫ СВЯЗЫВАЕМ НАШИ РЕЗУЛЬТАТЫ С ТАКСОНОМИЧЕСКОЙ МОДЕЛЬЮ ПРОСОДИИ ЗАИМСТВОВАНИЙ В (Davis et al.2012) И ВЫСКАЗЫВАЕМ ПРЕДПОЛОЖЕНИЯ О ПОСЛЕДСТВИЯХ, КОТОРЫЕ ЭТИ РЕЗУЛЬТАТЫ МОГУТ ИМЕТЬ ДЛЯ ТОНОЛОГИИ БАМАНСКОЙ ПРОСОДИЧЕСКОЙ СТРУКТУРЫ, А ТАКЖЕ ТАКОВОЙ В ДРУГИХ ЯЗЫКАХ МАНДЕ.

INDEX

Keywords: prosodic structure, tonal melody, loanword phonology, Arabic, Bambara, Mande motsclesru ПРОСОДИЧЕСКАЯ СТРУКТУРА, ТОНАЛЬНЫЙ КОНТУР, ФОНОЛОГИЯ ЗАИМСТВОВАНИЙ, АРАБСКИЙ ЯЗЫК, ЯЗЫК БАМАНА, ЯЗЫКИ МАНДЕ

Mots-clés: structure prosodique, mélodie tonale, phonologie des emprunts, arabe, bambara, Mandé

\section{AUTHORS}

\section{CHRISTOPHER R. GREEN}

Syracuse University

cgreen10@syr.edu

\section{JENNIFER HILL BOUTZ}

University of Maryland-CASL 